\title{
CAMINHOS PARA O EMPREENDEDORISMO: UMA TIPOLOGIA DE ACESSO À ATIVIDADE EMPREENDEDORA
}

\section{Maria das Dores Guerreiro - ISCTE Instituto Universitário de Lisboa ${ }^{1}$ Ana Caetano - ISCTE Instituto Universitário de Lisboa ${ }^{2}$ Eduardo Rodrigues - ISCTE Instituto Universitário de Lisboa ${ }^{3}$ Margarida Barroso - ISCTE Instituto Universitário de Lisboa Ana Isabel Couto - ISCTE Instituto Universitário de Lisboa $^{5}$}

Resumo: Este artigo tem por objetivo central analisar os fatores sociais que, de forma articulada, explicam a decisão de uma pessoa se tornar empreendedora. Para o efeito é mobilizada informação recolhida no âmbito de um projeto de investigação realizado em Portugal direcionado para o estudo dos padrões, contextos e experiências de empreendedorismo. Com base na componente qualitativa da pesquisa, relativa à análise de entrevistas aprofundadas a mulheres e homens empreendedores sobre os seus trajetos individuais, foi elaborada uma tipologia de acesso à empresarialidade. Esta categorização expressa diferentes combinações de fatores, dando particular destaque aos efeitos que o género e as qualificações têm na opção de trabalhar por conta própria, sem deixar de enfatizar a interligação com as inserções socioeconômicas, as redes interpessoais e as relações familiares.

Palavras-chave: Empreendedorismo; Fatores sociais; Gênero.

\section{PATH TO ENTREPRENEURSHIP: A TYPOLOGY OF ACCESS TO ENTREPRENEURSHIP}

Abstract: This article intends to analyse the factors that explain why a person decides to become an entrepreneur, using data from a research project that studied entrepreneurial patterns, contexts and experiences. Based on the qualitative element of the research, which entailed examining in-depth interviews of both women and men entrepreneurs about their individual trajectories, we propose a typology of access to entrepreneurship. This categorisation expresses different combinations of

\footnotetext{
${ }^{1}$ E.mail: maria.guerreiro@iscte.pt - Endereço: Edifício ISCTE, Av. das Forças Armadas, Lisboa, Portugal. CEP: 1649-026

${ }^{2}$ E.mail: ana.caetano@iscte.pt

${ }^{3}$ E.mail: eduardo.rodrigues@iscte.pt

${ }^{4}$ E.mail: margarida.barroso@iscte.pt

${ }^{5}$ E.mail: ana_isabel_couto@iscte.pt
}

GUERREIRO, M. D.; CAETANO, A.; RODRIGUES, E.; BARROSO, M.; COUTO, A. I. Caminhos para o empreendedorismo: uma tipologia de acesso à atividade empreendedora. Revista de Empreendedorismo e Gestão de Pequenas Empresas, v.2,n.3, 2013. 
factors and places particular emphasis on the effects that gender and qualifications have on the decision to become self-employed, without neglecting the importance of socioeconomic circumstances, interpersonal networks and family relationships.

Keywords : Entrepreneurship ; Social factors ; Gender.

\section{Introdução}

O empreendedorismo enquanto fenómeno social, económico e cultural tem ganhado relevo nos últimos anos em diferentes esferas de ação. Assume particular destaque nos discursos político e mediático como via de superação das dificuldades decorrentes da situação financeira europeia. É frequentemente apresentado como alavanca de desenvolvimento económico da Europa e enquanto meio de redução do desemprego (ROBSON et al., 2009). Com efeito, tem-se verificado um forte investimento em políticas públicas de concessão de apoios e incentivos vários ao empreendedorismo. Na Europa foram produzidas orientações estratégicas e diferentes tipos de ações a este respeito, que assentam essencialmente na promoção da cultura empreendedora entre os jovens por via da educação para o empreendedorismo, na melhoria e no estímulo ao financiamento por entidades diversificadas, na redução da complexidade e burocracia associadas à criação de empresas, no aumento da tolerância face ao risco e na orientação para o crescimento e competitividade (OECD, 2012).

Esta atenção reforçada resultou na atribuição de meios - materiais e culturais - a futuros empreendedores por parte de iniciativas estatais e privadas, de âmbito europeu, nacional ou mais local, mas veio também promover o debate em torno dos fatores em que assenta 0 sucesso das experiências individuais de empreendedorismo. Em última instância, o impacto e o alcance destas iniciativas dependem do conhecimento produzido a esse respeito. No sentido de melhor orientar os apoios e garantir a sua eficácia, sabendo exatamente que recursos devem ser atribuídos e que competências estimuladas, é fundamental identificar os

GUERREIRO, M. D.; CAETANO, A.; RODRIGUES, E.; BARROSO, M.; COUTO, A. I. Caminhos para o empreendedorismo: uma tipologia de acesso à atividade empreendedora. Revista de Empreendedorismo e Gestão de Pequenas Empresas, v.2,n.3, 2013. 
fatores decisivos que explicam que os indivíduos se tornem em empreendedores e que os seus projetos sejam bem sucedidos.

É neste âmbito, com a finalidade de compreender o fenómeno do empreendedorismo e, assim, informar políticas públicas, que se insere o projeto de investigação do qual decorre o presente artigo. A pesquisa, intitulada "Gênero, Empreendedorismo e Qualificações: tendências, contextos e experiências individuais" (GEQ), tem por principal objetivo examinar os padrões e dinâmicas de empreendedorismo, bem como a forma como os mesmos afetam o funcionamento quotidiano das pequenas e médias empresas e os percursos de vida dos empreendedores (AUTOR et al., 2011). Em particular, procurou-se perceber, com base na realidade portuguesa - enquadrada no contexto europeu -, as práticas de empreendedorismo a partir de uma perspectiva de género, dando também destaque ao papel que as qualificações formais desempenham, em articulação com fatores como a idade e a classe social.

Para a prossecução dos objetivos do projeto foram definidas e mobilizadas, de forma articulada, diferentes estratégias metodológicas na constituição de uma abordagem com múltiplos níveis. Em nível estrutural foram analisados indicadores nacionais e europeus de empreendedorismo, foram identificadas e exploradas iniciativas públicas e privadas de promoção das práticas empreendedoras e foi realizada uma análise de imprensa com base na recolha de notícias sobre empreendedorismo dos principais jornais portugueses. Já no nível organizacional, foi aplicado um questionário online e foram realizados estudos de caso em diversas empresas portuguesas. Para o nível individual, realizaram-se entrevistas aprofundadas a mulheres e homens empreendedores, no sentido de compreender em concreto como se manifestam nas experiências individuais os padrões estruturais e organizacionais de capacitação e de constrangimento da iniciativa empreendedora.

O presente artigo tem por enfoque esta componente mais micro da pesquisai. Foram entrevistadas 23 pessoas que criaram projetos empresariais (de pequena e GUERREIRO, M. D.; CAETANO, A.; RODRIGUES, E.; BARROSO, M.; COUTO, A. I. Caminhos para o empreendedorismo: uma tipologia de acesso à atividade empreendedora. Revista de Empreendedorismo e Gestão de Pequenas Empresas, v.2,n.3, 2013. 
média dimensão) e que ilustram diferentes perfis de empreendedorismo. O objetivo central do texto passa por apresentar uma tipologia de acesso à empresarialidade que possibilita identificar e refletir sobre os principais fatores que explicam a decisão de mulheres e homens se tornarem empreendedores. A análise centra-se, portanto, numa fase inicial dos processos de empreendedorismo, respeitante à decisão de criar o próprio negócio, não abrangendo as variáveis que explicam as formas de implementação, gestão e o sucesso dos projetos empresariais criados.

Antes da apresentação e discussão da tipologia importa, contudo, identificar as coordenadas teóricas centrais da pesquisa e, assim, posicioná-la em alguns dos principais debates em torno do empreendedorismo, em particular nas duas dimensões centrais da análise - género e qualificações -, sem nunca perder de vista a sua interligação com outros fatores de ordem social, como sejam as origens sociais, a classe social, a experiência profissional prévia e as redes interpessoais e familiares.

\section{Empreendedorismo, gênero e qualificações}

Por ser frequentemente veiculado em diferentes esferas de discurso, alvo de apropriações públicas e políticas diversas e, ainda, analisado por várias áreas disciplinares, o conceito de empreendedorismo requer um esforço particular de clarificação analítica. O projeto GEQ tem uma ancoragem de base sociológica e é, por isso, orientado por coordenadas disciplinares da sociologia. Ainda assim, considerou-se fundamental garantir alguma abertura interdisciplinar e incorporar também contributos analíticos e operatórios de áreas de estudo como a psicologia social, a gestão ou a economia. O conceito de empreendedorismo é entendido, neste âmbito, como a criação de novas empresas por parte de indivíduos que fazem uso de recursos de diversa ordem (materiais, simbólicos, logísticos) que encontram nos seus enquadramentos socioeconômicos e culturais, de modo a concretizarem projetos de natureza econômica (ALDRICH, 2005; AUDRETSCH, 2002;

GUERREIRO, M. D.; CAETANO, A.; RODRIGUES, E.; BARROSO, M.; COUTO, A. I. Caminhos para o empreendedorismo: uma tipologia de acesso à atividade empreendedora. Revista de Empreendedorismo e Gestão de Pequenas Empresas, v.2,n.3, 2013. 
THORNTON, 1999). Assume-se, portanto, como fenômeno sociocultural, afetado por variáveis estruturais e contextuais, que ajudam a explicar as iniciativas individuais dos empreendedores (THORNTON et al., 2011; URBANO et al., 2011; WELTER, 2011).

A literatura sobre o empreendedorismo tem-se frequentemente deparado com algumas interrogações que introduzem o gênero numa posição fundamental e necessária para as pesquisas sobre o tema (BRUSH, 2008; ELAM, 2008; FISCHER ET AL., 1993; GARCIA; WELTER, 2011; KOBEISSI, 2010). Desde logo, porque motivos as mulheres criam negócios com menos frequência que os homens e, quando o fazem, tal ocorre em atividades bastante diferentes? Embora em anos mais recentes a criação de negócios por parte de mulheres se tenha tornado mais comum, o empreendedorismo enquanto conjunto de práticas e representações continua a surgir como uma instituição caracterizada por profundas diferenças de gênero. Tomando por referência o contexto português, veja-se, por exemplo, que apesar de a taxa de empreendedorismo (TEA - Early-stage entrepreneurial activity rate) ter vindo a aumentar nos últimos dois anos para as mulheres (de 4.7 em 2010 para 6.2 em 2012), apresenta ainda assim valores inferiores aos registrados para os homens (10.5 em 2010 e 9.3 em 2012) (XAVIER et al., 2013). Não só entram em menor número do que os homens na atividade empreendedora, como o fazem muitas vezes em áreas distintas e têm ambições e atitudes diferentes face ao empreendedorismo (KELLEY et al., 2013).

Muitas das pesquisas feitas acerca das experiências femininas de empreendedorismo têm-se centrado na identificação de similaridades e diferenças entre mulheres e homens detentores de negócios e na tentativa de explicação dos padrões encontrados (ARENIUS; KOVALAINEN, 2006; MARLOW et al., 2009; ROBICHAUD et al., 2007; VERHEUL; THURIK, 2001). Em termos gerais, podem ser destacados dois eixos explicativos que contribuem, de forma complementar, para compreender o impacto do género no empreendedorismo.

GUERREIRO, M. D.; CAETANO, A.; RODRIGUES, E.; BARROSO, M.; COUTO, A. I. Caminhos para o empreendedorismo: uma tipologia de acesso à atividade empreendedora. Revista de Empreendedorismo e Gestão de Pequenas Empresas, v.2,n.3, 2013. 
Em primeiro lugar, atenção particular deve ser concedida às dinâmicas de conciliação entre vida profissional e contextos familiares. O autoemprego ou a criação de empresas por parte das mulheres têm que ser perspectivados no enquadramento das responsabilidades tradicionalmente assumidas por estas no desempenho de formas de trabalho não pago, como as tarefas domésticas e os cuidados prestados a filhos e dependentes.

Várias mudanças societais tiveram impacto sobre os padrões familiares de divisão do trabalho doméstico. À medida que as mulheres começaram a trabalhar mais fora de casa e a passarem mais tempo "fora" da família, também começaram, claro, a trabalhar menos dentro de casa (CROMPTON, 1999). A questão tem que ser colocada, contudo, num plano relacional: no respeitante às responsabilidades e tarefas domésticas, e ao contrário das mulheres, os homens não "mudaram" em igual escala. A maioria do trabalho não pago continua a ser da responsabilidade das mulheres, o que significa que, num contexto de taxas crescentes de atividade feminina e de números cada vez maiores de mulheres a desenvolverem atividades de autoemprego e de criação de empresas, a maior parte delas enfrenta ainda uma segunda jornada ou, na terminologia de Hochschild (1989), um "segundo turno" quando chegam a casa do trabalho remunerado (AUTOR, 2011; AUTOR et al., 2009). Entre outras implicações, isso significa também que novos problemas e tensões relacionados com a conciliação entre trabalho pago e vida familiar são desigualmente distribuídos entre mães e pais, revelando as mulheres níveis de stress mais elevados, no que respeita a este interface família-trabalho (BEHAM et al., 2011; CROMPTON, 2006; AUTOR et al., 2007; AUTOR et al., 2009; AUTOR et al., 2008; LEWIS et al., 2011; PRÄG et al., 2011). A acumulação de tarefas em ambas as esferas constitui-se como obstáculo à assunção de responsabilidades laborais acrescidas decorrentes do trabalho por conta própria.

Em segundo lugar, sendo um fenômeno compreensível através da conjugação de fatores de ordem econômica, social e interpessoal, o empreendedorismo tem também que ser perspectivado como incorporando uma GUERREIRO, M. D.; CAETANO, A.; RODRIGUES, E.; BARROSO, M.; COUTO, A. I. Caminhos para o empreendedorismo: uma tipologia de acesso à atividade empreendedora. Revista de Empreendedorismo e Gestão de Pequenas

Empresas, v.2,n.3, 2013. 
dimensão cultural (BRUNI et al., 2004, 2005). Modelos específicos de masculinidades estão incorporados nas práticas e nos valores geralmente associados ao empreendedorismo, sendo que as culturas de negócio, produzidas e reproduzidas através da sucessão de ações e interações contextualmente situadas, podem ser lidas segundo uma legenda que ilustre as suas marcas de gênero: nos tipos de negócio, nos estilos de gestão, nas atitudes face ao empreendedorismo, nas formas de apresentação do corpo perante os outros (ANDERSON, 2008; CRAMER et al., 2012; FENWICK, 2002A; JONES, 2012, KANTER, 1993; POWELL, 2010; VERHEUL et al., 2002). Para isso, é necessário atentar às características e especificidades discursivas e narrativas das mulheres e homens empreendedores: como se apresentam a si mesmos, o que significa ser empreendedor, o que os distingue e aproxima que retóricas de auto apresentação usam, como caracterizam a sua atividade por contraste com outras (BRUNI et al., 2005; LEWIS, 2006).

No quadro de uma dimensão culturalista de investigação acerca dos discursos e narrativas que participam na definição de empreendedorismos "masculinos" e "femininos", deve também haver espaço para a identificação do potencial para a agência (GIDDENS, 1984), nomeadamente por parte das mulheres. Através das suas práticas e atitudes, executadas quotidianamente como detentoras de um negócio, criam formas de empreender renovadas ou alternativas que são em simultâneo formas inovadoras de construção de gênero e de prática de empreendedorismo (ANDERSON, 2008; FENWICK, 2002b). É aqui que pode ser feita uma articulação, por exemplo, com a problemática das qualificações: o acesso das mulheres a programas de aprendizagem de empreendedorismo tem originado nalguns casos a colocação em prática não apenas de novas competências técnicas e empresariais como também de atitudes mais gerais conducentes à expressão de iniciativas culturais inovadoras (BOTHA et al., 2006; CARTER, 2000).

A ideia de que os/as empreendedores/as nascem e não se fazem, embora seja ainda uma ideologia presente em diferentes tipos de discursos, tem vindo a perder terreno (GORMAN et al., 1997; KURATKO, 2005; MAN, 2006). O crescente GUERREIRO, M. D.; CAETANO, A.; RODRIGUES, E.; BARROSO, M.; COUTO, A. I. Caminhos para o empreendedorismo: uma tipologia de acesso à atividade empreendedora. Revista de Empreendedorismo e Gestão de Pequenas Empresas, v.2,n.3, 2013. 
número de estudos sobre este tema, que reconhecem o impacto positivo da educação nesta área para a criação de novas empresas, é disso evidência (BLOCK et al., 2013; MATLAY, 2008). É também cada vez mais frequente a publicação e divulgação de guias, bem como de biografias e autobiografias de empreendedores bem-sucedidos que partilham os seus conhecimentos, as suas experiências e identificam os fatores-chave para o sucesso dos seus negócios. Mesmo quando prevalece a noção de que os/as empreendedores/as têm algo inato que os leva a enveredarem por determinado percurso profissional, esse discurso começa também a ser complementado com a ideia de que alguns atributos pessoais podem ser estimulados e desenvolvidos (KURATKO, 2005). Esta noção assume particular importância para a integração de grupos sociais menos representados, como é o caso das mulheres, na atividade empresarial por via da educação para o empreendedorismo (BOTHA et al., 2006).

A pesquisa realizada neste âmbito sugere uma ligação clara entre níveis de escolaridade e atividade empreendedora, sendo que quanto mais elevado o número de anos de estudo, maior é a probabilidade de um indivíduo optar por trabalhar por conta própria e ser bem-sucedido em termos de crescimento, lucros e remunerações do novo negócio (BLOCK et al., 2013; MATLAY, 2008; NABI; HOLDEN, 2008). É neste sentido que a relação entre empreendedorismo e qualificações tem sido analisada, sobretudo por referência ao ensino superior (GARCIA et al., 2012; NABI et al., 2006; PITTAWAY; COPE, 2007; RASMUSSEN, 2011; TAATILA, 2010), em consonância com as preocupações e com o que tem sido o discurso que informa as políticas públicas, nomeadamente ao nível europeu. Contudo, é também importante ter em conta a expansão expressiva de cursos vocacionados para outro tipo de populações, nomeadamente com níveis de escolaridade mais baixos, que caracterizam alguns segmentos do tecido empresarial português (COSTA et al., 2009). Neste âmbito, a análise do impacto das qualificações deve também incorporar esta via de obtenção de conhecimentos e competências, ainda que dela não resulte a obtenção de um diploma.

GUERREIRO, M. D.; CAETANO, A.; RODRIGUES, E.; BARROSO, M.; COUTO, A. I. Caminhos para o empreendedorismo: uma tipologia de acesso à atividade empreendedora. Revista de Empreendedorismo e Gestão de Pequenas

Empresas, v.2,n.3, 2013. 
A bibliografia que se debruça sobre esta temática sugere que existem diferentes formas de se aprender a ser empreendedora. Os processos de aprendizagem das competências mobilizadas para as atividades empreendedoras não se restringem apenas ao contexto escolar ou a formações direcionadas para o empreendedorismo. Neste sentido, é fulcral integrar na análise não só os conhecimentos obtidos através das experiências dos indivíduos (ao longo das suas trajetórias de vida e nos seus quotidianos) em diferentes esferas de vida, particularmente a do trabalho, como também as vivências de familiares e amigos enquanto fonte de aprendizagem.

A incorporação de disposições favoráveis à atividade empreendedora por via da formação escolar pode, de facto, não significar a sua mobilização se os contextos em que os indivíduos se movem não o requererem. Inversamente, baixos níveis de qualificação podem ser compensados, de certa forma, pelas vivências que os indivíduos têm em contextos favoráveis ao empreendedorismo. Pode também dar-se - caso de elevados níveis de escolaridade serem complementados com enquadramentos que estimulam a atividade empreendedora. Significa, portanto, que analisar a influência das qualificações implica olhar de forma atenta para os contextos em que as mesmas são mobilizadas.

As experiências prévias de empreendedorismo podem ser importantes fontes de aquisição e de desenvolvimento de competências centrais para a fundação de uma empresa. A formação de uma ideia de negócio, a criação dos produtos, a definição de uma estratégia de entrada no mercado de trabalho, a gestão quotidiana da empresa: são etapas e momentos importantes de obtenção de conhecimentos (NABI et al., 2006). Mesmo as situações menos bem sucedidas constituem circunstâncias de aprendizagem, na medida em que potenciam a reflexão sobre os fatores que contribuíram para essa ocorrência.

As vivências que os indivíduos têm no mercado de trabalho, mesmo que a trabalharem por conta de outrem, podem também desempenhar um papel importante a este nível pelo contacto próximo que muitas vezes se proporciona com GUERREIRO, M. D.; CAETANO, A.; RODRIGUES, E.; BARROSO, M.; COUTO, A. I. Caminhos para o empreendedorismo: uma tipologia de acesso à atividade empreendedora. Revista de Empreendedorismo e Gestão de Pequenas

Empresas, v.2,n.3, 2013. 
as dinâmicas quotidianas de uma empresa. Este potencial é exponenciado quando existe alguma proximidade com os membros fundadores e com a direção.

A importância das experiências prévias estende-se às redes familiares e de sociabilidade dos indivíduos. O contacto próximo com familiares ou amigos que desenvolveram atividades empreendedoras proporciona a partilha de conhecimentos e experiências que podem vir a ser bastante úteis na decisão de um indivíduo se tornar empreendedor e na forma como essa opção de carreira é concretizada (GREVE; SALAFF, 2003; KURATKO, 2005; NABI; HOLDEN, 2008). No caso de empreendedores (as) jovens, com pouca experiência, a importância das redes e do capital social é ainda maior, na medida em que podem proporcionar apoio, aconselhamento e recursos que teriam de ser conseguidos por outras vias e de forma mais complexa (ANDERSON et al., 2007; CASSON; GIUSTA, 2007; CLERCQ; VORONOV, 2009; COPE et al., 2007; KIM; ALDRICH, 2005).

No fundo, gênero e qualificações, enquanto dimensões centrais da pesquisa aqui em discussão, não devem ser pensadas de forma isolada, mas como atuando em articulação permanente com outros fatores sociais, como sejam a classe social, as redes interpessoais, a experiência profissional ou as relações familiares, que podem ter impacto na opção de criar uma empresa e nos percursos biográficos dos empreendedores.

\section{Metodologia}

A análise do empreendedorismo, em articulação com estas duas dimensões (gênero e qualificações), é aqui levada a cabo com base na componente qualitativa do projeto GEQ. Deverá, contudo, ser realçado que, apesar de serem centrais, estes dois eixos analíticos, articulam-se com outras dimensões na explicação dos caminhos para o empreendedorismo.

O objetivo central é compreender, no nível individual, as trajetórias de empreendedorismo de um grupo diversificado de mulheres e homens portugueses GUERREIRO, M. D.; CAETANO, A.; RODRIGUES, E.; BARROSO, M.; COUTO, A. I. Caminhos para o empreendedorismo: uma tipologia de acesso à atividade empreendedora. Revista de Empreendedorismo e Gestão de Pequenas Empresas, v.2,n.3, 2013. 
que trabalham por conta própria. Para o efeito, foram contatadas diversas organizações empresariais de jovens empreendedores, agências de financiamento, iniciativas locais e nacionais, bem como programas públicos de apoio, que facultaram informação relevante sobre empresas e respectivos empreendedores: área de atividade, tipo de negócio, perfil do empreendedor, características da empresa. Com base nestes dados foram selecionados 23 empreendedores (16 mulheres e sete homens) com idades compreendidas entre os 24 e os 56 anos, que criaram um negócio próprio. Ao longo do artigo vão ser referidos por nomes fictícios, de modo a preservar o seu anonimato.

Porque interessava compreender, em particular, formas de empreendedorismo protagonizadas por mulheres e por indivíduos qualificados, a proporção de empreendedoras do sexo feminino, bem como a de empreendedores com um diploma de ensino superior (que são simultaneamente os mais jovens) não representam certos segmentos da população empresarial portuguesa. As origens sociais, as inserções de classe e as experiências profissionais dos empreendedores entrevistados são diversificadas, assim como as áreas de atividade das suas empresas e a sua localização geográfica em Portugal. Não tendo a representatividade estatística por finalidade, estes foram os principais critérios de seleção, visando captar um conjunto diferençado de situações.

Em geral, trata-se de empresas de pequena e média dimensão, que correspondem ao padrão empresarial do país. As entrevistas foram individuais, de cariz biográfico, e centraram-se no trajeto profissional dos entrevistados, mas sempre em articulação com dimensões de vida centrais na compreensão das escolhas laborais, como a família ou as sociabilidades. Foram realizadas no local de trabalho, registradas em áudio e posteriormente transcritas. A análise ancorou em diferentes eixos analíticos: história da empresa, caracterização da empresa, recursos humanos, condições de trabalho, trajeto pessoal do/a dirigente (caracterização social, formação, experiências anteriores, relação entre esferas de vida), conjuntura atual do país e futuro da empresa, e representações sobre GUERREIRO, M. D.; CAETANO, A.; RODRIGUES, E.; BARROSO, M.; COUTO, A. I. Caminhos para o empreendedorismo: uma tipologia de acesso à atividade empreendedora. Revista de Empreendedorismo e Gestão de Pequenas Empresas, v.2,n.3, 2013. 
empreendedorismo e gênero. Estas dimensões foram exploradas através da elaboração de retratos sociológicos, seguindo a proposta de Bernard Lahire (2004). O retrato sociológico é um instrumento de análise que, através da descrição interpretativa do percurso de vida em diferentes esferas de existência, permite perceber a produção social dos indivíduos através da interligação de caminhos e escolhas individuais com enquadramentos e campos de possibilidade estruturais.

Não se pretendeu que este conjunto de pessoas fosse representativo da realidade portuguesa ou europeia. O objetivo desta análise mais focada passa essencialmente por explorar a articulação de fatores sociais que explicam práticas individuais de empreendedorismo num conjunto diversificado de pessoas. Para esse efeito, foi elaborada uma tipologia de acesso à empresarialidade, composta por cinco categorias de empreendedorismo: jovem qualificado, para a conciliação de esferas de vida, de empresarialização da atividade profissional anterior, de emancipação e familiar.

\section{Perfis de empreendedorismo}

Esta tipologia de acesso ao empreendedorismo define-se pela articulação entre razões para se tornarem empreendedores com os contextos sociais em que essa decisão foi tomada. Ou seja, combina motivações e opções individuais de empreendedorismo com os enquadramentos sociais em que os entrevistados vivem e com os recursos estruturais a que neles têm acesso. Cada empreendedor foi associado a apenas uma das categorias da tipologia, de acordo com a intersecção de fatores que explicam o seu caminho para o empreendedorismo.

É obviamente uma análise circunscrita, mas ainda assim permite explorar, como se verá, processos mais alargados que contribuem para perceber o que leva uma pessoa a tornar-se empreendedora.

GUERREIRO, M. D.; CAETANO, A.; RODRIGUES, E.; BARROSO, M.; COUTO, A. I. Caminhos para o empreendedorismo: uma tipologia de acesso à atividade empreendedora. Revista de Empreendedorismo e Gestão de Pequenas

Empresas, v.2,n.3, 2013. 


\section{Empreendedorismo jovem qualificado}

O empreendedorismo jovem qualificado caracteriza-se por agregar iniciativas empresariais em áreas inovadoras ou de base tecnológica, como seja, por exemplo, o fabrico e comercialização de brinquedos científicos, de fragrâncias ou de kits de produção doméstica de cogumelosii (quadro 1). A característica central evidenciada pelos/as jovens empreendedores/as que se enquadram neste tipo de perfil de empreendedorismo é o elevado nível de qualificações formais. Iniciaram as suas atividades empresariais impulsionados/as pela vontade de aplicarem as suas competências escolares e também profissionais, entretanto adquiridas no decorrer de percursos que, sendo relativamente breves, foram relevantes para a decisão de criar uma empresa.

GUERREIRO, M. D.; CAETANO, A.; RODRIGUES, E.; BARROSO, M.; COUTO, A. I. Caminhos para o empreendedorismo: uma tipologia de acesso à atividade empreendedora. Revista de Empreendedorismo e Gestão de Pequenas Empresas, v.2,n.3, 2013. 
Quadro 1: Entrevistados do perfil de empreendedorismo jovem qualificado

\begin{tabular}{|c|c|c|c|c|c|c|c|}
\hline \multirow[b]{2}{*}{ Nome } & \multicolumn{4}{|c|}{ Empreendedor/a } & \multicolumn{3}{|c|}{ Empresa } \\
\hline & Sexo & Idade & $\begin{array}{l}\text { Nível de } \\
\text { escolaridade }\end{array}$ & $\begin{array}{l}\text { Estado } \\
\text { civil }\end{array}$ & Actividade & $\begin{array}{l}\text { Ano de } \\
\text { criação }\end{array}$ & $\begin{array}{l}\text { № } \\
\text { trab. }\end{array}$ \\
\hline Mário Mota & $M$ & 25 & $\begin{array}{l}\text { Mestrado em } \\
\text { Gestão }\end{array}$ & Solteiro & $\begin{array}{l}\text { Produção de } \\
\text { brinquedos } \\
\text { didáticos }\end{array}$ & 2008 & 8 \\
\hline $\begin{array}{l}\text { Alexandra } \\
\text { Machado }\end{array}$ & $\mathrm{F}$ & 28 & $\begin{array}{l}\text { Pós-graduação } \\
\text { em Marketing } \\
\text { Digital }\end{array}$ & Casada & Gestão de marcas & 2009 & 3 \\
\hline $\begin{array}{l}\text { Susana } \\
\text { Ferro }\end{array}$ & $\mathrm{F}$ & 38 & $\begin{array}{l}\text { Doutoramento } \\
\text { em Gestão } \\
\text { Econômica }\end{array}$ & Solteira & Design de cortiça & 2005 & 5 \\
\hline $\begin{array}{l}\text { Marina } \\
\text { Antunes }\end{array}$ & $\mathrm{F}$ & 33 & $\begin{array}{l}\text { Licenciatura em } \\
\text { Gestão }\end{array}$ & Solteira & $\begin{array}{l}\text { Produção em } \\
\text { poliuretano }\end{array}$ & 1997 & 9 \\
\hline Jorge Hilário & $M$ & 36 & $\begin{array}{l}\text { Doutoramento } \\
\text { em } \\
\text { Microbiologia }\end{array}$ & Casado & $\begin{array}{l}\text { Kits de produção } \\
\text { doméstica de } \\
\text { cogumelos }\end{array}$ & 2007 & 0 \\
\hline $\begin{array}{l}\text { Isabel } \\
\text { Soares }\end{array}$ & $\mathrm{F}$ & 40 & $\begin{array}{l}\text { Doutoramento } \\
\text { em Química }\end{array}$ & $\begin{array}{l}\text { Casada } \\
\text { (2 filhas) }\end{array}$ & $\begin{array}{l}\text { Produção de } \\
\text { fragrâncias }\end{array}$ & 2004 & 0 \\
\hline
\end{tabular}

Fonte: Projecto GEQ

Os entrevistados identificados como pertencentes a este perfil distinguem-se pela assunção clara de um projeto individual de vida em que a dimensão empreendedora e até "criadora" assume grande importância. Aqui, os estilos de vida integram uma dedicação aos respectivos projetos empresariais, que é consumidora de tempo e de energias, mas que é assumida como fundamental para o "sucesso". Daí que a variável idade seja especialmente relevante para este perfil-tipo, na maioria dos seus casos, já que implica uma determinada organização (exigente) do tempo e um conjunto de horizontes ambicionados que, noutros perfis de empreendedorismo, são condicionados por uma articulação distinta entre

GUERREIRO, M. D.; CAETANO, A.; RODRIGUES, E.; BARROSO, M.; COUTO, A. I. Caminhos para o empreendedorismo: uma tipologia de acesso à atividade empreendedora. Revista de Empreendedorismo e Gestão de Pequenas Empresas, v.2,n.3, 2013. 
componentes de estruturação das vivências individuais: uma vida familiar mais sedimentada ou uma conciliação trabalho-família mais exigente, por exemplo.

"Isto é a minha vida 24 horas, eu sonho com isto e levo para casa trabalho, vou pensar, vou a um centro comercial vou às lojas, vou ao fim de semana dar uma volta pelos centros comerciais correctos onde estão os Toys'R'Us, as Fnacs, etc. Não é como aquele trabalho em que uma pessoa entra às $9 \mathrm{~h}$ e sai às $17 \mathrm{~h}$ e a partir daí está noutra dimensão, isso não é. (...) É importante uma pessoa ter uma disponibilidade total para exercer a questão do empreendedorismo. (...) É importante de uma certa forma, se uma pessoa quer começar do zero mesmo, como é o nosso caso, em que comecei mesmo do zero, é importante que não tenha que ir buscar os filhos às $17 \mathrm{~h}$, que não tenha que ir ter com a mulher fazer...ou seja, é importante essa liberdade de horário e que muitas vezes chega a uma certa altura e as pessoas já não têm porque já tem um background familiar." (Mário Mota, 25 anos, empresa de produção de brinquedos didácticos)

As organizações lideradas por estes empreendedores são geralmente pequenas e ágeis na sua estrutura, caracterizadas por alguma informalidade de processos. Assim, as empresas em causa têm geralmente "a cara" do empreendedor, não tendo ainda tempo de vida suficiente para ficarem muito complexas. Essa agilidade abre também espaço para algum experimentalismo organizativo e para a implementação de vetores de inovação e produtos ou serviços de base tecnológica, algo que surge muitas vezes associado à vontade inicial de criação de um quadro empresarial passível de testar ou implementar ideias novas. Existe, portanto, uma assimilação destas empresas às figuras dos empreendedores e das empreendedoras, confundindo-se a história das primeiras com o percurso pessoal, as características e as opções dos segundos.

"Isto é um sonho meu, a empresa é minha, é aquilo que eu quis criar. (...) sou eu que estou aqui, a Design de Cortiça é a minha identidade.

O conceito de Design de Cortiça é meu, sou eu, representa-me." (Susana Ferro, 38 anos, empresa de design de cortiça).

GUERREIRO, M. D.; CAETANO, A.; RODRIGUES, E.; BARROSO, M.; COUTO, A. I. Caminhos para o empreendedorismo: uma tipologia de acesso à atividade empreendedora. Revista de Empreendedorismo e Gestão de Pequenas Empresas, v.2,n.3, 2013. 
Contudo, vale a pena destacar que existem algumas diferenças, mesmo no interior deste tipo de empreendedorismo, que parecem estar ligadas à influência do gênero, mais particularmente à adesão diferenciada que ressonâncias culturais mais individualizadas ou coletivistas de percurso empresarial podem encontrar entre homens e mulheres. Aqui podemos começar a falar de uma tendência notória, por parte das jovens mulheres empreendedoras para uma preocupação vincada com o "fator humano" da empresa, enquanto que nos homens entrevistados isso ficou mais para segundo plano (VERHEUL et al., 2002). De fato, foi nas entrevistas às empreendedoras que surgiu com mais frequência a ideia de que as empresas que criaram passaram entretanto a ser também "dos trabalhadores", como se aquilo que se iniciou como um projeto puramente pessoal fosse adquirindo uma "personalidade coletiva".

\begin{abstract}
"Aliás neste momento se o lucro fosse mais importante para mim eu não tinha a estrutura que tenho e estava eu a receber ordenado. Ainda não recebo salário nenhum da empresa, tenho pessoas na empresa a ganharem $1000 €$ por mês e eu ainda não recebo nada. Para mim é mais importante a estrutura, as pessoas. (...) Mas é mais importante para mim a motivação deles e saber que posso contar com eles. (...) eu envolvo-me demasiado com os colaboradores e com os próprios clientes emocionalmente." (Alexandra Machado, 28 anos, empresa de gestão de marcas)
\end{abstract}

Quando foi pedido na entrevista um esforço de prospecção para o futuro foram também as jovens mulheres, mais que os homens, que referiram com mais intensidade a possibilidade de emergirem dificuldades futuras de conciliação de uma carreira empresarial com a vida familiar.

A análise das principais características do empreendedorismo jovem qualificado permite identificar dois eixos que, em convergência, estruturam este tipo de perfil. O primeiro assenta na relevância dos fatores de qualificação formal que contribuem, em grande parte, para a explicação dos percursos empreendedores. As

GUERREIRO, M. D.; CAETANO, A.; RODRIGUES, E.; BARROSO, M.; COUTO, A. I. Caminhos para o empreendedorismo: uma tipologia de acesso à atividade empreendedora. Revista de Empreendedorismo e Gestão de Pequenas

Empresas, v.2,n.3, 2013. 
qualificações destes indivíduos surgem ao nível do ensino pós-graduado e todos reconhecem as suas credenciais e aprendizagens como determinantes por facultarem um conjunto de acessos, recursos, conhecimentos gerais e especializados mobilizáveis nos seus trajetos empreendedores. As elevadas qualificações a nível técnico podem ainda ser fundamentais a vários níveis: desde a definição das áreas de atividade das empresas criadas, mas também aos tipos de produtos e serviços oferecidos, imbuídos de componentes apreciáveis de inovação. O elevado nível de qualificações também pode ser associado a uma maior agilidade na aquisição de informação ou mesmo de outros recursos que advém de inserções em redes de promoção e apoio ao empreendedorismo qualificado (GOIS; MACHADO, 2012; RIBEIRO; TEIXEIRA, 2012; PITTAWAY et al., 2010). Na realidade, a maioria destes empreendedores recorreu a programas de apoio (nacionais e europeus) para aquisição de equipamento, investimento na internacionalização e atribuição de instalações para a empresa.

Um segundo eixo de análise e diferenciação, embora indissociável do nível de qualificação destes empreendedores, diz respeito à componente inovadora ou de base tecnológica introduzida nos produtos ou serviços que as empresas disponibilizam, existindo em quase todos os casos uma estreita relação com a investigação desenvolvida em meio acadêmico. Nesta vertente de análise é de destacar que às qualificações formais obtidas em meio acadêmico se associou a manutenção de vias comunicantes com contextos de investigação. Isso se traduziu, em alguns casos, não apenas na criação de redes de circulação continuada de informação e recursos mas também na implementação de atividades comerciais com componentes incorporadas de conhecimento científico.

Atendendo a estes dois eixos de análise, é importante também reforçar o papel transversal, por vezes subtil, mas que não deve ser menosprezado, das origens sociais em primeiro lugar, e das redes de interconhecimento num segundo momento.

GUERREIRO, M. D.; CAETANO, A.; RODRIGUES, E.; BARROSO, M.; COUTO, A. I. Caminhos para o empreendedorismo: uma tipologia de acesso à atividade empreendedora. Revista de Empreendedorismo e Gestão de Pequenas Empresas, v.2,n.3, 2013. 
Alguns dos/as entrevistados/as que podem ser alocados a este perfil específico detêm origens sociais associadas à acumulação de recursos econômicos, mas também culturais e sociais cuja importância para percursos de vida que enveredem pela empresarialidade não deve ser esquecida. $O$ acesso a patamares de qualificação ao nível do ensino superior indicia, aliás, inserções de classe à partida mais favorecidas.

Autonomamente a esse fator, também a integração dos empreendedores e empreendedoras em redes densas de interconhecimento - seja num primeiro nível familiar de partilha de recursos econômicos, por exemplo, seja num segundo nível, acumulável ou não com o primeiro, de circulação de informação entre colegas ou contextos universitários, empresariais e mesmo políticos - assume papel importante numa articulação de fatores sociais que contribuem para explicar as tendências e o sucesso empreendedor dos indivíduos em causa.

Os capitais econômicos, culturais e também sociais de que alguns destes indivíduos dispõem encontram um lugar de destaque no conjunto de fatores que contribuem para compreender os percursos individuais. Contudo, no decorrer das entrevistas a importância destes elementos tendeu a ser diminuída pelos empresários e empresárias, especialmente daqueles com origens sociais mais privilegiadas, muito em linha com a presença (já esperada) de tonalidades de discurso marcadas pela valorização pessoal e pelo destaque de qualidades individuais de persistência e vigor empreendedor.

"Não me venham dizer que um empreendedor aprende-se a ser na escola." (Alexandra Machado, 28 anos, empresa de gestão de marcas)

"Nunca desistir. Neste tipo de projectos é preciso ter uma insistência enorme e uma vontade muito grande de fazer mais e melhor todos os dias, por isso também é preciso acreditar muito e nunca atirar a toalha ao chão." (Mário Mota, 25 anos, empresa de produção de brinquedos didácticos)

GUERREIRO, M. D.; CAETANO, A.; RODRIGUES, E.; BARROSO, M.; COUTO, A. I. Caminhos para o empreendedorismo: uma tipologia de acesso à atividade empreendedora. Revista de Empreendedorismo e Gestão de Pequenas Empresas, v.2,n.3, 2013. 
Aliás, as "qualidades" pessoais referidas, e que são expressas pelos/as próprios entrevistados/as quando refletem sobre o que mais contribui para explicar os seus percursos, podem ser vistas como disposições - tenacidade, autonomia, independência, criatividade - que necessitam de condições específicas, porque escassas e desigualmente distribuídas, para serem "criadas". Essas condições, embora não forçosamente exclusivas de origens sociais privilegiadas, como alguns dos casos individuais também demonstram, estão, contudo associadas a determinados processos de socialização prática em contextos primários e secundários.

\section{Empreendedorismo para a conciliação de esferas de vida}

O empreendedorismo para a conciliação de esferas de vida caracteriza percursos de entrada na empresarialidade (em áreas tão distintas como a fotografia, a atividade física ou a exploração agrícola) motivados pela procura de equilíbrio no desempenho de diferentes papéis sociais. Os casos que integram este perfil distinguem-se dos restantes precisamente por considerarem que o trabalho por conta própria proporciona maior autonomia e melhor flexibilidade na gestão do tempo dedicado a diferentes domínios de vida. As motivações subjacentes a esta opção profissional remetem sobretudo para as dificuldades encontradas em experiências de trabalho anteriores na conciliação entre a esfera profissional e a vida familiar. Este perfil de empreendedorismo caracteriza-se, acima de tudo, pela tentativa de adaptação da vida profissional àquilo que são as exigências e responsabilidades familiares. Noutros perfis encontramos frequentemente a situação inversa, sendo em torno da esfera do trabalho que se organizam os tempos familiares e de lazer, por exemplo.

GUERREIRO, M. D.; CAETANO, A.; RODRIGUES, E.; BARROSO, M.; COUTO, A. I. Caminhos para o empreendedorismo: uma tipologia de acesso à atividade empreendedora. Revista de Empreendedorismo e Gestão de Pequenas Empresas, v.2,n.3, 2013. 
Quadro 2: Entrevistados do perfil de empreendedorismo para a conciliação de esferas de vida

\begin{tabular}{|c|c|c|c|c|c|c|c|}
\hline \multirow[b]{2}{*}{ Nome } & \multicolumn{4}{|c|}{ Empreendedor/a } & \multicolumn{3}{|c|}{ Empresa } \\
\hline & Sexo & Idade & $\begin{array}{l}\text { Nível de } \\
\text { escolaridade }\end{array}$ & $\begin{array}{l}\text { Estado } \\
\text { civil }\end{array}$ & Atividade & $\begin{array}{l}\text { Ano de } \\
\text { criação }\end{array}$ & $\begin{array}{l}\text { No } \\
\text { trab. }\end{array}$ \\
\hline $\begin{array}{l}\text { Rute } \\
\text { Bernardo }\end{array}$ & $F$ & 33 & $\begin{array}{l}\text { Mestrado em } \\
\text { Etologia }\end{array}$ & $\begin{array}{l}\text { Casada } \\
(2 \\
\text { filhas) }\end{array}$ & $\begin{array}{l}\text { Fotografia e } \\
\text { atividades em } \\
\text { família }\end{array}$ & 2009 & 2 \\
\hline $\begin{array}{l}\text { Alexandra } \\
\text { Silva }\end{array}$ & $\mathrm{F}$ & 45 & $\begin{array}{l}\text { Frequência } \\
\text { da } \\
\text { Licenciatura } \\
\text { de Gestão }\end{array}$ & $\begin{array}{l}\text { Casada } \\
(2 \\
\text { filhos) }\end{array}$ & $\begin{array}{l}\text { Ginásio } \\
\qquad \begin{array}{l}\text { (franchisi } \\
\text { ng) }\end{array}\end{array}$ & 2006 & 8 \\
\hline $\begin{array}{l}\text { Mariana } \\
\text { Seixas }\end{array}$ & $\mathrm{F}$ & 42 & $\begin{array}{l}3^{\circ} \text { Ciclo do } \\
\text { Ensino } \\
\text { Básico } \\
\text { (9 ano) }\end{array}$ & $\begin{array}{l}\text { Casada } \\
(2 \\
\text { filhos) }\end{array}$ & $\begin{array}{l}\text { Exploração } \\
\text { agrícola de } \\
\text { hortícolas em } \\
\text { estufas }\end{array}$ & 2008 & 20 \\
\hline
\end{tabular}

Fonte: Projecto GEQ

Integram esta categoria apenas empreendedoras do sexo feminino (quadro 2), o que por si só é revelador da persistência de dinâmicas genderizadas na conciliação entre trabalho e família. Não significa que para os homens entrevistados a questão familiar não seja também assumida como preocupação. Não foi, contudo, apontada no discurso masculino de empreendedorismo como motivação central para a criação do próprio emprego. No decurso das entrevistas realizadas, problemas relacionados com a gestão do tempo, cuidados prestados aos filhos e articulação

GUERREIRO, M. D.; CAETANO, A.; RODRIGUES, E.; BARROSO, M.; COUTO, A. I. Caminhos para o empreendedorismo: uma tipologia de acesso à atividade empreendedora. Revista de Empreendedorismo e Gestão de Pequenas

Empresas, v.2,n.3, 2013. 
com os horários laborais dos cônjuges surgiram mais frequentemente nos relatos das mulheres (mesmo nos das empreendedoras que integram outros perfis), do que nas narrativas dos homens (PATTERSON E MAVIN, 2009). Estes dados indiciam que as responsabilidades domésticas, de gestão quotidiana do agregado familiar, são, sobretudo assumidas pelas mulheres, que têm de articulá-las com o investimento paralelo na esfera laboral.

O efeito que as preocupações familiares tiveram nas opções profissionais das mulheres que integram este tipo de empreendedorismo fez-se sentir de duas formas distintas: por via da parentalidade ou por via da conjugalidade.

Nalguns casos, foi o fato de serem mães de crianças pequenas (com idades compreendidas entre um e 10 anos) que as levou a considerarem a viabilidade da opção do trabalho por conta própria. Curiosamente, para uma das mulheres, a própria definição do negócio resultou de preocupações associadas à maternidade: criou uma empresa de fotografia familiar e investiu em particular na fotografia de recém-nascidos. A inserção profissional prévia à atividade empresarial, embora não fosse incompatível com as responsabilidades parentais destas empreendedoras, dificultava o envolvimento que pretendiam ter na vida quotidiana dos filhos. Trabalhar por conta própria abriu novas possibilidades de organização flexível dos tempos do trabalho e da vida familiar.

"Em dias normais eu trabalho 20 horas por dia (...) mas se, por qualquer razão, houver a necessidade de fazer um shut down ao trabalho porque alguma das minhas filhas está doente, eu sou provavelmente a mãe mais privilegiada do mundo porque eu faço um hold a tudo o que existe na minha vida para ficar em casa com elas. Portanto, a gestão das minhas prioridades está muito clara na minha cabeça, a minha prioridade é a minha família, ponto final. " (Rute Bernardo, 33 anos, empresa de fotografia e actividades familiares)

O fato de poderem controlar, em larga medida, a alocação do seu tempo, permite-Ihes colocar em segundo plano o projeto empreendedor sempre que os

GUERREIRO, M. D.; CAETANO, A.; RODRIGUES, E.; BARROSO, M.; COUTO, A. I. Caminhos para o empreendedorismo: uma tipologia de acesso à atividade empreendedora. Revista de Empreendedorismo e Gestão de Pequenas Empresas, v.2,n.3, 2013. 
filhos necessitam de cuidados imediatos. Não é tanto por disporem de mais tempo no trabalho por conta própria, mas sim por poderem geri-lo autonomamente. Para além disso, nalguns casos a atividade empresarial implicou também a relocalização do local de trabalho, que passou a ser mais próximo de casa.

\footnotetext{
"Uma das vantagens que eu neste momento tenho é estar mais perto dos meus filhos. Se for preciso, se alguém me telefonar, não tenho que dar satisfações. Falo com a minha colaboradora e digo "olha, eu vou ter de sair. Ficas aqui." $E$ tenho apoio nisso, enquanto que se fosse noutro sítio não tinha. Para mim, é uma das vantagens enquanto mulher." (Alexandra Silva, 45 anos, ginásio)
}

Apesar de o projeto empreendedor exigir um forte investimento pessoal, nomeadamente em termos de tempo e atenção, todas elas enfatizaram que as orientações de futuro das suas empresas se encaminham para a profissionalização do negócio, com uma equipa especializada, que implique em médio-longo prazo, um menor centramento da empresa na figura do empreendedor e que, por isso, requeira menor envolvimento da sua parte.

Noutros casos, embora minoritários, foi por via da conjugalidade, e não da parentalidade, que se consubstanciou a opção de criar o próprio negócio. Em face de mudanças residenciais decorrentes quer de uma nova relação conjugal, quer de alteração do posto de trabalho do marido, algumas mulheres abandonaram as atividades profissionais por conta de outrem que exerciam. Estas alterações introduzidas nas suas vidas para seguirem os cônjuges constituíram o impulso necessário para investirem naquilo que já alimentavam como projeto profissional há algum tempo. Apesar da situação de desemprego em que se encontravam momentaneamente, encararam esta mudança como oportunidade (para criarem a próprio negócio, mas também de valorização pessoal) e não como constrangimento, sem nunca porem em causa o exercício de uma atividade remunerada.

Os casos que integram o perfil de empreendedorismo para a conciliação de esferas de vida permitem dar conta do impacto que a vida familiar pode ter na GUERREIRO, M. D.; CAETANO, A.; RODRIGUES, E.; BARROSO, M.; COUTO, A. I. Caminhos para o empreendedorismo: uma tipologia de acesso à atividade empreendedora. Revista de Empreendedorismo e Gestão de Pequenas Empresas, v.2,n.3, 2013. 
decisão dos indivíduos, em particular das mulheres, se tornarem empreendedores (ANNINK; DEN DULK, 2012; CRAIG et al., 2012; HUGHES, 2003). Acima de tudo, possibilitam compreender os efeitos que as responsabilidades associadas à família podem ter nas escolhas profissionais das mulheres. O empreendedorismo é neste sentido entendido como via profissional facilitadora da articulação entre a carreira e a vida familiar, mesmo que para algumas mulheres a atividade empresarial implique, pelo menos provisoriamente, uma maior dedicação ao trabalho do que exigia o exercício de uma atividade profissional por conta de outrem. A ideia fundamental a reter da análise destes casos é que para estas empresárias o empreendedorismo surgiu como solução para um investimento simultâneo no trabalho e na família, sem que sentissem ser necessário fazer uma escolha unilateral entre as duas esferas de vida.

Importa ainda referir que a decisão de criar o próprio emprego não dependeu, nos casos aqui analisados, exclusivamente de fatores familiares. A procura de equilíbrio entre papéis sociais pode ter sido a motivação principal, mas essa opção foi potenciada por outros fatores, como o acesso a recursos, a posse de competências especializadas (formais ou informais) ou a existência de redes de apoio (nomeadamente familiares, ver EDDLESTON ;POWELL, 2012). E é desses fatores, em última instância, que depende a sustentabilidade das empresas em médio e longo prazo.

\section{Empreendedorismo de empresarialização da atividade profissional anterior}

Este tipo de empreendedorismo caracteriza percursos de entrada na empresarialidade que decorrem diretamente de experiências profissionais prévias. Ou seja, os empreendedores que integram este perfil tomaram a opção de criarem empresas na mesma área de atividade em que anteriormente exerciam funções, geralmente enquanto trabalhadores por conta de outrem (AUTOR, 2001). Incluem-se neste âmbito áreas tão diversificadas como, por exemplo, a estética, a publicidade, a GUERREIRO, M. D.; CAETANO, A.; RODRIGUES, E.; BARROSO, M.; COUTO, A. I. Caminhos para o empreendedorismo: uma tipologia de acesso à atividade empreendedora. Revista de Empreendedorismo e Gestão de Pequenas 
animação turística, a cutelaria ou a impressão gráfica. Esta decisão decorre de diferentes circunstâncias e enquadramentos, a que importa aqui atentar (quadro 3).

Quadro 3: Entrevistados do perfil de empreendedorismo de empresarialização da atividade profissional anterior

\begin{tabular}{|c|c|c|c|c|c|c|c|}
\hline & \multicolumn{4}{|c|}{ Empreendedor/a } & \multicolumn{3}{|c|}{ Empresa } \\
\hline Nome & Sexo & Idade & $\begin{array}{l}\text { Nível de } \\
\text { escolaridade }\end{array}$ & $\begin{array}{l}\text { Estado } \\
\text { civil }\end{array}$ & Atividade & $\begin{array}{l}\text { Ano de } \\
\text { criação }\end{array}$ & $\begin{array}{l}\text { № } \\
\text { trab. }\end{array}$ \\
\hline Ângela Gil & $\mathrm{F}$ & 49 & $\begin{array}{l}\text { Licenciatura em } \\
\text { Dietética e } \\
\text { Nutrição }\end{array}$ & $\begin{array}{l}\text { Casada } \\
\text { (1 filho) }\end{array}$ & Spa & 2003 & 8 \\
\hline $\begin{array}{l}\text { Goreti } \\
\text { Morais }\end{array}$ & $\mathrm{F}$ & 50 & $\begin{array}{l}\text { 3ํ Ciclo Ensino } \\
\text { Básico ( } 9^{\circ} \text { ano) }\end{array}$ & Casada & Cabeleireiro & 2009 & 0 \\
\hline $\begin{array}{l}\text { Maria } \\
\text { Santos }\end{array}$ & $\mathrm{F}$ & 27 & $\begin{array}{l}\text { 3 Ciclo Ensino } \\
\text { Básico (9ª ano) }\end{array}$ & $\begin{array}{l}\text { Casada } \\
\text { (1 filho) }\end{array}$ & Cabeleireiro & 2009 & 0 \\
\hline $\begin{array}{l}\text { Rute } \\
\text { Belchior }\end{array}$ & $\mathrm{F}$ & 36 & $\begin{array}{l}\text { Licenciatura em } \\
\text { Design de } \\
\text { Comunicação }\end{array}$ & $\begin{array}{l}\text { Casada } \\
\text { (1 filha) }\end{array}$ & $\begin{array}{l}\text { Marketing e } \\
\text { publicidade }\end{array}$ & 2001 & 55 \\
\hline $\begin{array}{l}\text { Fernando } \\
\text { Guedes }\end{array}$ & $M$ & 32 & $\begin{array}{l}\text { Licenciatura em } \\
\text { Educação Física }\end{array}$ & $\begin{array}{l}\text { Casado } \\
\text { (2 filhos) }\end{array}$ & Animação turística & 2008 & 2 \\
\hline $\begin{array}{l}\text { Sónia } \\
\text { Garcia }\end{array}$ & $\mathrm{F}$ & 34 & $\begin{array}{l}\text { Licenciatura em } \\
\text { Ciências do } \\
\text { Desporto }\end{array}$ & $\begin{array}{l}\text { Divorciada } \\
\text { (1 filho) }\end{array}$ & Animação turística & 2004 & 2 \\
\hline $\begin{array}{l}\text { José } \\
\text { Ferreira }\end{array}$ & M & 57 & $\begin{array}{l}\text { 1 Ciclo Ensino } \\
\text { Básico (4ํano) }\end{array}$ & $\begin{array}{l}\text { Divorciado } \\
\text { (5 filhos) }\end{array}$ & Cutelaria & 1998 & 4 \\
\hline $\begin{array}{l}\text { Vasco } \\
\text { Gomes }\end{array}$ & M & 55 & $\begin{array}{l}\text { 3ํ Ciclo Ensino } \\
\text { Básico ( } 9^{\circ} \text { ano) }\end{array}$ & $\begin{array}{l}\text { Casado } \\
\text { (2 filhos) }\end{array}$ & Gráfica & 1982 & 44 \\
\hline
\end{tabular}

Fonte: Projecto GEQ

Em alguns casos resulta de uma situação de desemprego. Em face de dificuldades encontradas numa nova inserção profissional no mercado de trabalho, estes entrevistados definiram com alternativa para superar a inatividade laboral, a GUERREIRO, M. D.; CAETANO, A.; RODRIGUES, E.; BARROSO, M.; COUTO, A. I. Caminhos para o empreendedorismo: uma tipologia de acesso à atividade empreendedora. Revista de Empreendedorismo e Gestão de Pequenas Empresas, v.2,n.3, 2013. 
elaboração de um plano empresarial próprio. Para esse efeito, consideraram que seria determinante para o sucesso do projeto mobilizar aquelas que tinham sido as competências adquiridas ao longo dos seus trajetos profissionais, optando, nesse sentido, por montar um negócio na mesma área de atividade.

Neste perfil de empreendedorismo a decisão de se tornarem empresários decorreu também, e para a maior parte dos empreendedores, de insatisfação com a sua situação profissional de trabalho por conta de outrem. Apesar de apreciarem a área de atividade em que trabalhavam, foram desenvolvendo algum descontentamento relativamente à falta de autonomia que tinham na gestão das suas tarefas quotidianas. Consideravam que 0 seu trabalho se encontrava excessivamente formatado, com pouca margem para proporem novas atividades e serviços para o desenvolvimento de certas áreas da empresa. Nalguns casos, esta insatisfação acumulava ainda desagrado com os níveis remuneratórios auferidos. Tomaram, então, a decisão de criar o seu próprio projeto laboral, elaborado com base na mesma área de trabalho.

"Teve uma época em que estava muito insatisfeita com o tipo de trabalho que fazia ali. Não tinha nada a ver comigo." (Goreti Morais, 50 anos, cabeleireiro)

"Acho que foi o querer abraçar projectos, querer ser independente, não estar a depender dos outros. Ter um projecto que me dissesse que eu que ia-me realizar e depois partilhar esse projecto com as pessoas que me rodeiam." (Vasco Gomes, 55 anos, gráfica)

"Eu estava numa fase em que tinha cerca de quatro ou cinco anos de experiência de trabalho, os últimos três passados na empresa multinacional, em que o ritmo de trabalho era de tal forma alucinante e absorvente que eu não conseguia ter vida própria. (...) Decidi arriscar." (Rute Belchior, 36 anos, empresa de marketing e publicidade)

"Trabalhava nesta área há 13 anos, (...) estive na gestão de spa's de hotéis, mas a dada altura achei que estava em tempo de começar a

GUERREIRO, M. D.; CAETANO, A.; RODRIGUES, E.; BARROSO, M.; COUTO, A. I. Caminhos para o empreendedorismo: uma tipologia de acesso à atividade empreendedora. Revista de Empreendedorismo e Gestão de Pequenas Empresas, v.2,n.3, 2013. 
pensar em montar qualquer coisa (...) era sobretudo instituir a minha ideia, porque quando trabalhamos para outras pessoas temos de nos adaptar àquilo que está instituído pela empresa, (...) daí ter decidido de facto fazer qualquer coisa nuns moldes diferentes daquilo que existe." (Ângela Gil, 49 anos, spa)

Noutros casos ainda, embora minoritários nesta amostra, o acesso à empresarialidade resultou de experiências prévias de empreendedorismo mal sucedidas. A falta de experiência, o desentendimento entre sócios (quanto aos objetivos, formas de gestão e futuro da empresa), a elaboração de um projeto empresarial desajustado ao mercado ou à realidade económica nacional e a escassez de recursos materiais são apontados por estes empreendedores como fatores decisivos para que uma primeira incursão como trabalhadores por conta própria não tenha resultado. Mas apesar de terem fechado as empresas que inicialmente criaram, não entendem estas experiências profissionais de empreendedorismo como tendo sido inteiramente negativas. Acima de tudo, foram tentativas que serviram como palco de experimentação e possibilitaram, através da acumulação de competências e recursos, a definição e consolidação dos atuais projetos empreendedores, que, entretanto já implementaram de forma mais consolidada.

Não pode também deixar de ser referido que a concepção, bem como a implementação de um plano profissional alternativo (como resposta ao desemprego, à insatisfação com o trabalho por conta de outrem ou a experiências prévias de negócios mal sucedidos) só pôde ser levada a cabo porque estes empreendedores tinham a possibilidade de mobilizarem recursos, estavam integrados em redes sólidas de apoio (material, motivacional, de partilha de experiências), ou contaram com suporte financeiro e logístico de programas públicos ou privados. De qualquer forma, independentemente do tipo de apoio com que contaram, todos eles têm em comum a capitalização de competências acumuladas ao longo de percursos profissionais prévios, geralmente de alguns anos, na mesma área de atividade.

GUERREIRO, M. D.; CAETANO, A.; RODRIGUES, E.; BARROSO, M.; COUTO, A. I. Caminhos para o empreendedorismo: uma tipologia de acesso à atividade empreendedora. Revista de Empreendedorismo e Gestão de Pequenas Empresas, v.2,n.3, 2013. 


\section{Empreendedorismo de emancipação}

O empreendedorismo de emancipação caracteriza percursos de acesso à empresarialidade como forma de ruptura com contextos profissionais por conta de outrem vivenciados de forma negativa (quadro 4).

Quadro 4: Entrevistados do perfil de empreendedorismo de emancipação

\begin{tabular}{|c|c|c|c|c|c|c|c|}
\hline \multirow[b]{2}{*}{ Nome } & \multicolumn{4}{|c|}{ Empreendedor/a } & \multicolumn{3}{|c|}{ Empresa } \\
\hline & Sexo & Idade & $\begin{array}{l}\text { Nível de } \\
\text { escolaridade }\end{array}$ & $\begin{array}{l}\text { Estado } \\
\text { civil }\end{array}$ & Actividade & $\begin{array}{l}\text { Ano de } \\
\text { criação }\end{array}$ & $\begin{array}{l}\text { № } \\
\text { trab. }\end{array}$ \\
\hline $\begin{array}{l}\text { Carla } \\
\text { Adriano }\end{array}$ & $F$ & 38 & $\begin{array}{l}\text { Ensino } \\
\text { Secundário (12o } \\
\text { ano) }\end{array}$ & $\begin{array}{l}\text { Casada } \\
\text { (2 filhos) }\end{array}$ & Costura & 2010 & 0 \\
\hline Luísa Silva & $\mathrm{F}$ & 55 & $\begin{array}{l}3^{0} \text { ciclo do } \\
\text { Ensino Básico } \\
\text { (9ำano) }\end{array}$ & $\begin{array}{l}\text { Casada } \\
\text { (2 filhos) }\end{array}$ & Limpeza & 2010 & 0 \\
\hline $\begin{array}{l}\text { Jorge } \\
\text { Vicente }\end{array}$ & M & 36 & $\begin{array}{l}\text { Licenciatura em } \\
\text { Ciências da } \\
\text { Comunicacãa }\end{array}$ & Solteiro & Artesanato & 2006 & 0 \\
\hline
\end{tabular}

Fonte: Projecto GEQ

Para alguns destes entrevistados os seus trajetos laborais anteriores são marcados por precariedade, baixos salários e atividades pouco qualificadas. Para outros se verifica um acentuado afastamento das suas profissões e condições de trabalho face às suas ambições profissionais e de vida. Em ambas as situações há uma clara insatisfação face ao tipo de tarefas desempenhadas, à área de atividade, à pouca criatividade e autonomia que têm na gestão do trabalho e às fracas remunerações. Partilham, portanto, com alguns dos empreendedores do perfil anterior (de empresarialização da atividade profissional prévia) a insatisfação com os contextos de trabalho por conta de outrem. Contudo, diferem num aspeto decisivo:

GUERREIRO, M. D.; CAETANO, A.; RODRIGUES, E.; BARROSO, M.; COUTO, A. I. Caminhos para o empreendedorismo: uma tipologia de acesso à atividade empreendedora. Revista de Empreendedorismo e Gestão de Pequenas Empresas, v.2,n.3, 2013. 
se os primeiros dão continuidade à profissão prévia, os que integram este perfil, por outro lado, procuram a emancipação através da ruptura com essa atividade profissional.

"Ultimamente estava a ficar horrível, não conseguia mesmo lá estar (...) estávamos com muitos problemas, os colegas iam-se embora, fiquei praticamente sozinha e tive encontrar uma solução. (...) Tinha que fazer de secretária, telefonista, vendedora, angariadora e mesmo assim o patrão nunca estava satisfeito. O mercado baixou muito, comecei a ter problemas de saúde e o meu médico aconselhou-me a deixar o trabalho. (...) Eu não queria estar no desemprego e queria trabalhar para mim, criar o meu próprio posto de trabalho. E então foi com o apoio do Centro de Emprego que eu abri a minha empresa." (Luísa Silva, 55 anos, empresa de limpezas)

"A ideia foi fruto de uma experiência que eu decidi fazer num determinado momento da minha vida, quando não tinha trabalho efectivo." (Jorge Vicente, 36 anos, empresa de artesanato)

Isso não significa, por outro lado, que os percursos profissionais anteriores não tenham efeito nas iniciativas empresariais que desenvolveram designadamente através das competências que foram necessárias mobilizar quer para o momento de criação das empresas, quer para o seu funcionamento diário. Nestes casos, apenas não têm um reflexo imediato ou estruturador no que à definição da área de atividade diz respeito.

Os empreendedores que integram este perfil alimentavam há já muitos anos a vontade de trabalharem por conta própria, por acreditarem que a criação de uma empresa seria a melhor solução para resolverem a sua insatisfação laboral e melhorarem as suas condições de trabalho. A elaboração de novos planos profissionais, por via do empreendedorismo, surge associada à redefinição de projetos de vida. A mudança profissional corresponde, no fundo, a uma viragem identitária, no sentido em que procuram uma atividade mais próxima dos seus interesses pessoais, da sua postura face à vida e das suas ambições de futuro.

GUERREIRO, M. D.; CAETANO, A.; RODRIGUES, E.; BARROSO, M.; COUTO, A. I. Caminhos para o empreendedorismo: uma tipologia de acesso à atividade empreendedora. Revista de Empreendedorismo e Gestão de Pequenas Empresas, v.2,n.3, 2013. 
Pretendem, assim, melhorar as suas condições de existência, do ponto de vista material pelo acesso a remunerações mais elevadas, mas também simbólico, encontrando bem-estar emocional na superação de dificuldades e na capacidade de reformularem e concretizarem objetivos de vida. Acabaram por investir em atividades em que acumularam interesse pessoal, mas também competências, por serem práticas que levam a cabo frequentemente. Trata-se, aliás, de um perfil constituído maioritariamente por mulheres empreendedoras que criaram empresas de prestação de serviços tradicionais (costura e limpeza).

Estes empreendedores são empresários em nome individual que montaram estruturas empresariais de micro dimensão e sem a contratação de trabalhadores. Embora exerçam as suas atividades empresariais de forma isolada, projetam para o futuro a integração de outras pessoas no negócio, de forma a permitir aumentar a capacidade produtiva e a captação de novos clientes. Estamos aqui perante projetos de pequena dimensão pelo fato de os entrevistados não terem acesso a meios que permitissem pensar e concretizar objetivos em maior escala. Na realidade, este perfil integra os empreendedores que, globalmente, têm origens sociais e inserções de classe mais desfavorecidas, bem como níveis de escolaridade mais baixos. A concretização dos seus planos empresariais dependeu, aliás, inteiramente da concessão de apoios públicos de suporte à criação do próprio emprego. O não acesso a programas de apoio (financeiro, logístico, de consultoria e de formação) teria por implicação direta o abandono do projeto de empreendedorismo. A dependência deste tipo de suporte evidencia a fragilidade deste grupo de empreendedores e coloca em questão a sustentabilidade dos seus projetos empresariais. Mudanças econômicas conjunturais e a cessação do contrato de apoio após a formação da empresa podem ter efeitos negativos (e determinantes) na continuidade dos seus negócios. O mesmo não se verificou, por exemplo, para os entrevistados dos restantes perfis, que mesmo tendo, nalguns casos, recorrido a suporte fornecido por iniciativas públicas similares, complementaram esse apoio com outro tipo de meios que tinham à disposição nos seus contextos de vida.

GUERREIRO, M. D.; CAETANO, A.; RODRIGUES, E.; BARROSO, M.; COUTO, A. I. Caminhos para o empreendedorismo: uma tipologia de acesso à atividade empreendedora. Revista de Empreendedorismo e Gestão de Pequenas

Empresas, v.2,n.3, 2013. 


\section{Empreendedorismo familiar}

Um último perfil identificado diz respeito aos casos de empresarialidade que surgem associados a um contexto familiar (quadro 5). Este tipo de empreendedorismo resulta de situações em que se dá continuidade a uma atividade empresarial pré-existente na família, como a produção de cortiça ou a metalomecânica, mas também de circunstâncias em que a criação de uma empresa resulta da associação de parentes na atividade empresarial, e/ou da mobilização de recursos familiares (humanos ou empresariais) na empresa criada.

Quadro 5: Entrevistados do perfil de empreendedorismo familiar

\begin{tabular}{|c|c|c|c|c|c|c|c|}
\hline & \multicolumn{4}{|c|}{ Empreendedor/a } & \multicolumn{3}{|c|}{ Empresa } \\
\hline Nome & Sexo & Idade & $\begin{array}{l}\text { Nível de } \\
\text { escolaridade }\end{array}$ & $\begin{array}{l}\text { Estado } \\
\text { civil }\end{array}$ & Actividade & $\begin{array}{l}\text { Ano de } \\
\text { criação }\end{array}$ & $\begin{array}{l}\text { № } \\
\text { trab. }\end{array}$ \\
\hline $\begin{array}{l}\text { Manuela } \\
\text { Sousa }\end{array}$ & $\mathrm{F}$ & 42 & $\begin{array}{l}3^{\circ} \text { Ciclo do } \\
\text { Ensino Básico } \\
\text { (9aa ano) }\end{array}$ & $\begin{array}{l}\text { Casada } \\
\text { (2 filhos) }\end{array}$ & Agricultura & 1993 & 6 \\
\hline $\begin{array}{l}\text { Sónia } \\
\text { Cardoso }\end{array}$ & $\mathrm{F}$ & 38 & $\begin{array}{l}\text { Doutoramento } \\
\text { em Gestão }\end{array}$ & Solteira & Cortiça & 1986 & 60 \\
\hline $\begin{array}{l}\text { Miguel } \\
\text { Abreu }\end{array}$ & M & 42 & $\begin{array}{l}\text { Bacharelato em } \\
\text { Gestão }\end{array}$ & $\begin{array}{l}\text { Casado } \\
\text { (2 filhos) }\end{array}$ & Metalomecânica & 1965 & 150 \\
\hline
\end{tabular}

Fonte: Projecto GEQ

A prossecução de um negócio criado por um familiar, geralmente pelo avô ou pelo pai, abre a possibilidade de uma inserção no mercado de trabalho mais facilitada. De fato, os entrevistados que integram este perfil reconhecem que, mesmo antes de definirem os seus projetos profissionais de futuro, tinham a segurança de poderem sempre incorporar os quadros da empresa da família. Esta

GUERREIRO, M. D.; CAETANO, A.; RODRIGUES, E.; BARROSO, M.; COUTO, A. I. Caminhos para o empreendedorismo: uma tipologia de acesso à atividade empreendedora. Revista de Empreendedorismo e Gestão de Pequenas Empresas, v.2,n.3, 2013. 
facilidade assume centralidade no discurso dos entrevistados, independentemente dos seus percursos escolares e das suas escolhas profissionais. Em nenhum dos casos, contudo, se pode afirmar que a inserção no negócio familiar tenha decorrido de experiências menos bem-sucedidas ou da dificuldade de inclusão no mercado de trabalho. O negócio montado e mantido pelos familiares passou, na realidade, a assumir-se como projeto pessoal e opção de vida destes empreendedores, ao invés de adquirir o estatuto de herança indesejada.

"Normalmente é difícil as pessoas acreditarem. Acham geralmente que isto são heranças. Foi, claramente, uma opção de vida." (Miguel Abreu, 42 anos, empresa de metal mecânica)

O contacto com o ambiente empresarial surge desde muito cedo nas suas biografias, confundindo-se, inclusive, a história da empresa com a história da família (AUTOR, 1996; HOWORTH ET al., 2010).

"Toda uma parte da família da qual eu faço parte foi sempre educada dentro da fábrica. Nós mantemos, ainda hoje, laços familiares muito estreitos e todos nós gravitamos um pouco à volta da fábrica." (Miguel Abreu, 42 anos, empresa de metal mecânica)

A convivência positiva continuada com e no espaço do negócio familiar contribuiu, nestes casos, para a incorporação de fortes disposições para o empreendedorismo, estimulando interesse e o desenvolvimento de competências empresariais. Os familiares que criaram a empresa são vistos como modelos a seguir, por terem sido bem-sucedidos e por estarem na origem da construção do património familiar.

A entrada na empresa da família surge geralmente, para este grupo de empreendedores, em funções mais subalternas, como via de aprendizagem das dinâmicas concretas do negócio. Mais tarde, e depois de acumulada experiência e conhecimento, chegam mesmo, nalgumas situações, a assumir a posição de

GUERREIRO, M. D.; CAETANO, A.; RODRIGUES, E.; BARROSO, M.; COUTO, A. I. Caminhos para o empreendedorismo: uma tipologia de acesso à atividade empreendedora. Revista de Empreendedorismo e Gestão de Pequenas Empresas, v.2,n.3, 2013. 
dirigentes, sobretudo quando o fundador se reforma numa lógica de sucessão (AUTOR, 1996; BORGES E LIMA, 2012; HOWORTH et al, 2001; ZELLWEGER et al., 2012). Para alguns destes empreendedores, a escolha da licenciatura obedeceu já à perspectiva de virem a assumir um cargo de dirigente. A promoção dentro da empresa tende a ser mais célere quando o empreendedor tem um diploma do ensino superior. Esta integração é geralmente bem recebida pela família, pelo facto de as competências obtidas em contexto acadêmico complementarem os conhecimentos adquiridos por via da experiência de muitos anos dos familiares que já lá trabalhavam. De fato, os entrevistados que completaram um curso no ensino superior trouxeram um novo impulso à empresa, nomeadamente pela forte aposta na sua modernização, creditação e expansão, mas também pela introdução de novos modelos de gestão e pela definição de rumos alternativos. Nalguns casos, a conjugação de um profundo conhecimento da área de atividade da empresa, com a experiência profissional adquirida nesse contexto e ainda com qualificações ao nível do ensino superior serviu de plataforma para o desenvolvimento de uma determinada ideia de negócio de forma integrada na empresa. Estes empreendedores criaram, no fundo, um novo ramo da empresa como projeto pessoal, mas sempre em articulação com o tipo de atividade do negócio familiar e recorrendo, para tal, aos meios que aí encontram à sua disposição.

O empreendedorismo familiar manifesta-se ainda por via da associação de membros da mesma família para iniciarem um projeto empresarial (BRANNON et al., 2013; CRUZ et al., 2013). Pela proximidade emocional e pela confiança que mantêm entre si, conjugam esforços, combinam propostas e planos e mobilizam recursos no sentido de criarem e implementarem uma ideia de negócio. Neste âmbito, é particularmente comum, entre os entrevistados, que a sociedade familiar surja por via da conjugalidade, sendo que frequentemente os homens ocupam a função de dirigentes e as mulheres assumem um papel com menor visibilidade, embora relevante nas dinâmicas de criação e funcionamento da empresa criada (AUTOR, 1996).

GUERREIRO, M. D.; CAETANO, A.; RODRIGUES, E.; BARROSO, M.; COUTO, A. I. Caminhos para o empreendedorismo: uma tipologia de acesso à atividade empreendedora. Revista de Empreendedorismo e Gestão de Pequenas

Empresas, v.2,n.3, 2013. 
"O nosso objetivo foi trabalhar enquanto casal, porque a empresa sendo, sobretudo familiar, seria mais rentável. A nossa empresa era quase só mão d obra familiar, os nossos pais trabalhavam conosco." (Manuela Sousa, 42 anos, empresa de agricultura)

Estas empresas, principalmente quando são de pequena ou média dimensão, tendem a integrar uma força de trabalho maioritariamente composta por membros da família, como cônjuges, pais, irmãos, tios ou primos. No caso dos entrevistados que integram este perfil, o negócio familiar era já pré-existente, mas a sua origem remonta a este tipo de dinâmicas, de associação entre parentes.

Porque se trata de uma integração numa empresa criada por outras pessoas, estamos perante um tipo de empreendedorismo com contornos diferentes dos restantes perfis, já que não foram os entrevistados a criarem de raiz o projeto empresarial. Contudo, considerou-se importante integrar o perfil familiar na discussão sobre fatores de empreendedorismo, pelo papel proativo e decisivo que estes empreendedores tiveram na atual configuração do negócio familiar, do qual passaram inclusive a ser dirigentes, na maioria dos casos. No fundo, criaram o seu próprio projeto no interior do projeto familiar já existente.

\section{Notas finais: fatores de empreendedorismo}

Em cada perfil de empreendedorismo encontra-se uma articulação singular de fatores que explica o acesso à empresarialidade. Estes indicadores conjugam-se de forma diferente para cada categoria da tipologia, mas também, em última instância, para cada pessoa. Ainda assim, a particularidade presente neste tipo de análise é expressão de dinâmicas e padrões sociais mais vastos, pelo que é possível, a partir do exame integrado de casos individuais, identificar um conjunto relevante de fatores sociais que explicam por que, como e em que condições uma pessoa se torna empreendedora. A listagem apresentada no quadro 6 sistematiza essa análise.

GUERREIRO, M. D.; CAETANO, A.; RODRIGUES, E.; BARROSO, M.; COUTO, A. I. Caminhos para o empreendedorismo: uma tipologia de acesso à atividade empreendedora. Revista de Empreendedorismo e Gestão de Pequenas Empresas, v.2,n.3, 2013. 


\section{Quadro 6: Fatores de empreendedorismo}

\begin{tabular}{l|l}
\hline \multicolumn{2}{c}{ Fatores de empreendedorismo } \\
\hline Qualificações & $\begin{array}{l}\text { Competências e conhecimento } \\
\text { Inovação }\end{array}$ \\
\hline Experiência profissional prévia & $\begin{array}{l}\text { De empreendedorismo } \\
\text { De apoio à gestão } \\
\text { Numa determinada área de atividade }\end{array}$ \\
\hline Recursos materiais & $\begin{array}{l}\text { Meios financeiros próprios } \\
\text { Acesso ao crédito } \\
\text { Instalações e equipamentos }\end{array}$ \\
\hline Apoio familiar & $\begin{array}{l}\text { Recursos financeiros } \\
\text { Instalações e equipamentos } \\
\text { Recursos humanos } \\
\text { Apoio à conciliação trabalho-família } \\
\text { Experiência profissional de familiares } \\
\text { Projeto familiar } \\
\text { Motivação }\end{array}$ \\
\hline Capital social & $\begin{array}{l}\text { Partilha de experiência, conhecimento e projetos } \\
\text { Motivação }\end{array}$ \\
\hline Programas de apoio (políticas & Financeiro \\
públicas) & Logístico \\
& Instalações e equipamento \\
\hline
\end{tabular}

Fonte: Projecto GEQ

Em primeiro lugar, deve ser dado destaque à importância das qualificações para a atividade empreendedora. A educação formal faculta conhecimento, competências, acesso a recursos e a informação. No patamar de ensino superior, em muitos contextos, é também estimulada a inovação e a criatividade e é promovida a integração dos indivíduos em redes interpessoais que partilham informação, recursos, objetivos e interesses empresariais. De fato, muitos dos casos aqui analisados correspondem a empreendedores jovens qualificados cujos negócios têm uma forte componente de inovação, assentando mesmo, nalguns casos, em fundamentos científicos, em articulação com investigação produzida em contexto universitário. Por não ser este o padrão empresarial em todos os contextos nacionais, como é o caso de Portugal, a decisão de investimento no empreendedorismo deve, para quem tem níveis de escolaridade mais baixos, ser

GUERREIRO, M. D.; CAETANO, A.; RODRIGUES, E.; BARROSO, M.; COUTO, A. I. Caminhos para o empreendedorismo: uma tipologia de acesso à atividade empreendedora. Revista de Empreendedorismo e Gestão de Pequenas Empresas, v.2,n.3, 2013. 
procurada noutros fatores sociais, como seja o apoio de redes familiares ou de políticas públicas.

A experiência prévia de trabalho é também crucial para se compreender a motivação associada à criação de uma empresa. Para alguns dos empreendedores entrevistados esta não é a primeira incursão no empreendedorismo. Nestes casos as vivências passadas a este nível são consideradas as fundações na aprendizagem de competências práticas e técnicas necessárias para a criação e gestão de um negócio próprio. Noutras circunstâncias, não é o envolvimento direto na criação da empresa. Muitos deles trabalharam com alguém próximo que era empreendedor e ajudaram-no em diferentes aspetos do trabalho quotidiano de gestão de uma empresa. Estes contextos de trabalho são também favoráveis no desenvolvimento de disposições, competências e motivação para o empreendedorismo. O trabalho por conta de outrem, como se viu, é também, nalgumas situações, uma plataforma de aprendizagem e de gestação de projetos empresariais, quer por estímulo positivo de investimento numa dada área de atividade, quer por contraste acentuado com ambições profissionais de futuro.

$\mathrm{Na}$ base de qualquer experiência de empreendedorismo estão os recursos materiais, tanto do ponto de vista financeiro, como em termos de instalações e equipamentos. Na implementação de uma ideia de negócio os empreendedores podem assumir uma postura mais autônoma se tiverem a possibilidade de mobilizar os seus próprios recursos sem necessitar de apoio externo. De fato, nalguns casos, geralmente de indivíduos com origens sociais mais favorecidas (em termos culturais e financeiros), fizeram uso de capital econômico acumulado e/ou de patrimônio predial para iniciarem as suas empresas. Noutras situações, o recurso ao crédito bancário é indispensável para levarem a cabo os seus planos empresariais, na formalização inicial do negócio, na aquisição de equipamento, no investimento em espaços de trabalho e na contratação de trabalhadores. Independentemente da forma como os obtêm, os recursos materiais são uma condição primária de viabilização, implementação e sustentabilidade de qualquer projeto empreendedor.

GUERREIRO, M. D.; CAETANO, A.; RODRIGUES, E.; BARROSO, M.; COUTO, A. I. Caminhos para o empreendedorismo: uma tipologia de acesso à atividade empreendedora. Revista de Empreendedorismo e Gestão de Pequenas

Empresas, v.2,n.3, 2013. 
O apoio familiar é também um fator social fulcral e deve ser devidamente considerado. Desde logo, a família faculta frequentemente suporte material, por via de recursos financeiros, bem como de instalações e equipamentos. Muitas vezes os membros familiares são mobilizados como recursos humanos para o novo negócio, seja inicialmente para apoiar, de modo mais informal, a elaboração e implementação do projeto, seja para mais tarde integrarem a força de trabalho da empresa. A família é também uma fonte importante de apoio à conciliação entre trabalho e vida familiar. Muitos dos empreendedores entrevistados, em particular aqueles que têm filhos, contam com a ajuda dos pais, avós e tios nos cuidados prestados às crianças, de modo a não comprometerem o projeto empresarial, sobretudo em fases que exigem maior atenção e dedicação. A família é ainda uma fonte de motivação e um contexto de partilha de experiências e conhecimento. É frequente entre os entrevistados recorrerem ao aconselhamento e ajuda de familiares que já tiveram experiências de empreendedorismo. Nalguns casos os empreendedores têm inclusive familiares como parceiros de negócio, tornando-se a empresa num projeto familiar.

Em certa medida, encontra-se também um tipo similar de apoio no seio das redes interpessoais dos empreendedores. Amigos, colegas de contexto escolar ou do trabalho podem prestar suporte financeiro, ajudar na elaboração do plano de negócios, facilitar empréstimos de dinheiro, espaços laborais ou equipamentos e podem inclusive tornar-se sócios, criando um projeto empresarial comum. Noutras situações, muitos entrevistados têm amigos que são empreendedores e contam, por isso, com os conselhos, experiências e conhecimentos provenientes das suas redes de capital social para tomarem decisões, mas também como fonte de motivação e inspiração.

Por fim, não pode deixar de ser referido o impacto de programas de apoio, sobretudo ligados a políticas públicas de promoção do empreendedorismo, a nível local, nacional ou europeu. Os empreendedores procuram este suporte em busca de financiamento, acesso a instalações e equipamentos e ajuda logística em termos de criação de um plano de negócio e de consultoria com especialistas de mercado ou GUERREIRO, M. D.; CAETANO, A.; RODRIGUES, E.; BARROSO, M.; COUTO, A. I. Caminhos para o empreendedorismo: uma tipologia de acesso à atividade empreendedora. Revista de Empreendedorismo e Gestão de Pequenas 
conselheiros financeiros. Em muitos casos é também facultada formação e educação para o empreendedorismo. Apesar de a maioria dos programas ser aberto a todas as pessoas interessadas, este tipo de apoio é mais importante, e tem mesmo um papel decisivo, para os menos qualificados e mais carenciados do ponto de vista económico, do que para os jovens qualificados ou para quem tem origens sociais mais favorecidas. Os apoios públicos permitem, no fundo, compensar a escassez, ou mesmo a inexistência, de diferentes tipos de recursos.

Em termos gerais, em cada um dos perfis de empreendedorismo discutidos no presente artigo é possível encontrar factores preponderantes (quadro 7).

GUERREIRO, M. D.; CAETANO, A.; RODRIGUES, E.; BARROSO, M.; COUTO, A. I. Caminhos para o empreendedorismo: uma tipologia de acesso à atividade empreendedora. Revista de Empreendedorismo e Gestão de Pequenas Empresas, v.2,n.3, 2013. 
Quadro 7: Perfis e fatores de acesso ao empreendedorismo

\begin{tabular}{|c|c|c|}
\hline $\begin{array}{l}\text { Perfil de acesso ao } \\
\text { empreendedorismo }\end{array}$ & Definição & $\begin{array}{l}\text { Factores } \\
\text { preponderantes }\end{array}$ \\
\hline Jovem qualificado & $\begin{array}{l}\text { Actividade empresarial em áreas inovadoras } \\
\text { ou de base tecnológica impulsionada pelo } \\
\text { desejo de aplicação de competências } \\
\text { académicas (ao nível do ensino superior) }\end{array}$ & $\begin{array}{l}\text { - Qualificações formais } \\
\text { - Capital social } \\
\text { - Acesso a recursos } \\
\text { materiais }\end{array}$ \\
\hline $\begin{array}{l}\text { Para a conciliação } \\
\text { de esferas de vida }\end{array}$ & $\begin{array}{l}\text { Entrada na empresarialidade motivada pela } \\
\text { procura de maior autonomia e flexibilidade } \\
\text { na gestão do tempo dedicado às diferentes } \\
\text { esferas de vida, em particular na articulação } \\
\text { trabalho-família }\end{array}$ & $\begin{array}{l}\text { - Maternidade } \rightarrow \text { Procura } \\
\text { de flexibilidade no apoio } \\
\text { à conciliação trabalho- } \\
\text { família } \\
\text { - Acesso a recursos } \\
\text { materiais }\end{array}$ \\
\hline $\begin{array}{l}\text { De } \\
\text { empresarialização } \\
\text { da atividade } \\
\text { profissional anterior }\end{array}$ & $\begin{array}{l}\text { Aplicação de competências adquiridas ao } \\
\text { longo do trajecto profissional prévio num } \\
\text { negócio por conta própria, na mesma área } \\
\text { de actividade }\end{array}$ & $\begin{array}{l}\text { - Experiência profissional } \\
\text { prévia } \\
\text { - Apoio familiar e de } \\
\text { amigos }\end{array}$ \\
\hline De emancipação & $\begin{array}{l}\text { Ruptura com contextos profissionais por } \\
\text { conta de outrem vivenciados de forma } \\
\text { negativa }\end{array}$ & $\begin{array}{l}\text { - Programas públicos de } \\
\text { apoio }\end{array}$ \\
\hline Familiar & $\begin{array}{l}\text { Continuidade da actividade empresarial pré- } \\
\text { existente na família }\end{array}$ & $\begin{array}{l}\text { - Projecto empresarial da } \\
\text { família: recursos, } \\
\text { instalações, experiência } \\
\text { profissional }\end{array}$ \\
\hline
\end{tabular}

Fonte: Projecto GEQ

O empreendedorismo jovem qualificado é fundamentalmente explicado pelas qualificações formais, em articulação com o capital social e com a posse ou acesso facilitado a recursos materiais. O empreendedorismo para a conciliação entre esferas de vida, com um cariz fortemente genderizado, está, sobretudo associado a

GUERREIRO, M. D.; CAETANO, A.; RODRIGUES, E.; BARROSO, M.; COUTO, A. I. Caminhos para o empreendedorismo: uma tipologia de acesso à atividade empreendedora. Revista de Empreendedorismo e Gestão de Pequenas Empresas, v.2,n.3, 2013. 
fatores de ordem familiar, em conjunção com o acesso a diferentes tipos de recursos. A empresarialização de uma ocupação prévia resulta da experiência profissional anterior, em articulação com o apoio prestado por redes (família, amigos). O empreendedorismo de emancipação ancora fortemente em programas públicos de apoio. E o empreendedorismo familiar deriva diretamente de fatores familiares. No entanto, é importante que fique claro que não é apenas um fator, do conjunto acima listado, que explica porque é que uma pessoa decide criar a sua própria empresa. É antes uma combinação de fatores, que pode ser variável para cada indivíduo e para cada tipo de empreendedorismo. Para além disso, cada fator pode ter um impacto diferenciado de acordo com a singularidade dos casos individuais.

A articulação de fatores que explica cada perfil de empreendedorismo é, em certa medida, indissociável do contexto socioeconômico português, o que é particularmente evidente em algumas categorias da tipologia. Por exemplo, o empreendedorismo de emancipação surge como resposta ao desemprego ou a condições de trabalho precárias que muitos segmentos da população enfrentam no país. O empreendedorismo familiar ilustra a forte presença de empresas de origem familiar no tecido econômico português. E o empreendedorismo para a conciliação de esferas de vida expressa as dificuldades que as mulheres enfrentam num país onde permanecem como as principais responsáveis pelo trabalho doméstico, apesar de a taxa de atividade feminina a tempo inteiro em Portugal estar acima da média da União Europeia.

Contudo, procurou-se também captar alguns segmentos emergentes da população empresarial portuguesa. Neste âmbito, foram identificadas categorias e fatores de acesso ao empreendedorismo que caracterizam dinâmicas europeias e globais. A este nível é particularmente importante destacar o papel desempenhado pela educação formal, em especial no patamar do ensino superior, e pelos programas de apoio (europeus, nacionais e locais). Recomendações e iniciativas europeias têm vindo a promover especificamente estes dois campos de acção. É GUERREIRO, M. D.; CAETANO, A.; RODRIGUES, E.; BARROSO, M.; COUTO, A. I. Caminhos para o empreendedorismo: uma tipologia de acesso à atividade empreendedora. Revista de Empreendedorismo e Gestão de Pequenas

Empresas, v.2,n.3, 2013. 
também por essa razão que é tão importante complementar a tipologia de caminhos para o empreendedorismo com a discussão dos principais fatores que a definem. Esta é o principal contributo da pesquisa. Os perfis podem ser variáveis consoantes os contextos nacionais, mas os fatores identificados remetem para dinâmicas e processos mais vastos e abrangentes. Podem, por isso, ser encontrados em diferentes enquadramentos estruturais, embora a sua articulação assuma potencialmente configurações distintas em cada um deles. $O$ gênero e as qualificações foram o ponto de partida do projeto GEQ, mas o enfoque nestas duas dimensões foi combinado com outros elementos explicativos que permitem um entendimento mais complexo e multidimensional do fenômeno social do empreendedorismo.

É ainda importante destacar que a tipologia apresentada decorre de uma abordagem sociológica do empreendedorismo. Existe já uma tradição consolidada de construção de tipologias associadas à atividade empreendedora em diferentes áreas de conhecimento (FILION, 1999, 2000; MARCHESNAY, 2011). De um modo geral, estas tipologias tendem a ser definidas tendo por base o tipo de negócio, as características das empresas, o sucesso dos projetos empreendedores, o estilo de gestão, as competências, traços de personalidade e motivação dos empreendedores e a sua visão de mercado. Tratando-se de elementos importantes de compreensão do fenômeno, ganham, contudo, do ponto de vista analítico, em ser complementados com fatores de ordem social, como os que foram discutidos neste artigo. Fatores individuais geralmente apontados na literatura já existente sobre a temática, como a iniciativa, a motivação e a persistência não resultam apenas de opções individuais, desconectadas da envolvente estrutural dos sujeitos. Para se perceber o que leva uma pessoa a tornar-se empreendedora é fundamental compreender os seus enquadramentos socioeconômicos, as suas esferas de socialização e a sua integração em redes sociais. No fundo, assumindo que ninguém nasce empreendedor, aquilo que se pretendeu aqui discutir, e que pode

GUERREIRO, M. D.; CAETANO, A.; RODRIGUES, E.; BARROSO, M.; COUTO, A. I. Caminhos para o empreendedorismo: uma tipologia de acesso à atividade empreendedora. Revista de Empreendedorismo e Gestão de Pequenas Empresas, v.2,n.3, 2013. 
enriquecer o debate em torno dos diferentes tipos de atividade empreendedora, foram as condições sociais de produção do empreendedorismo.

\section{Financiamento}

Esta pesquisa foi financiada pela Fundação para a Ciência e a Tecnologia e pela Comissão para a Cidadania e Igualdade de Género.

\section{Referências:}

ALDRICH H. E. Entrepreneurship. In: SMELSER, N. J.; SWEDBERG, R. (Eds.). The Handbook of Economic Sociology. New York: Princeton University Press, 2005, p. 451-477.

ANDERSON, E. R. 'Whose name's on the awning?' Gender, entrepreneurship and the American diner. Gender, Place and Culture. v. 15, n. 4, p. 395-410, 2008.

ANDERSON, A.; PARK, J.; JACK, S. Entrepreneurial social capital. Conceptualizing social capital in new high-tech firms. International Small Business Journal. v. 25, n. 3, p. 245-272, 2007.

ANNINK, A.; DEN DULK, L. D. Autonomy: the panacea for self-employed women's work-life balance?. Community, Work \& Family. v.15, n. 4, p. 383-402, 2012.

ARENIUS, P.; KOVALAINEN, A. Similarities and differences across the factors associated with women's self-employment preference in the Nordic countries. International Small Business Journal. v. 24, n.1, p. 31-59, 2006.

AUDRETSCH, D. B. Entrepreneurship. A Survey of the Literature. London: European Commission, 2002.

BEHAM, B.; ETHERINGTON, D.; RODRIGUES, E. Variations in work-life balance satisfaction among service sector employees. In: BACK-WIKLUND, M.; VAN DER LIPPE, T.; DEN DULK, L.; DOORNE-HUISKES, A. (Eds.). Quality of Life and Work in Europe. Theory, Practice and Policy. London: Palgrave, 2011, p.118-134.

GUERREIRO, M. D.; CAETANO, A.; RODRIGUES, E.; BARROSO, M.; COUTO, A. I. Caminhos para o empreendedorismo: uma tipologia de acesso à atividade empreendedora. Revista de Empreendedorismo e Gestão de Pequenas Empresas, v.2,n.3, 2013. 
BLOCK, J.H.; HOOGERHEIDE, L.; THURIK, R. Education and entrepreneurial choice. An instrumental variables analysis. International Small Business Journal. v. 31, n. 1, p. 23-33, 2013.

BORGES, A. F.; LIMA, J. B. O processo de construção da sucessão empreendedora em empresas familiares: um estudo multicaso. Revista de Empreendedorismo e Gestão de Pequenas Empresas, v. 1, n. 1, p. 131-154, 2012.

BOTHA, M.; NIEMAN, G.; VUUREN, J. V. Enhancing female entrepreneurship by enabling access to skills. International Entrepreneurship and Management Journal, v. 2, n. 4, p. 479-493, 2006.

BRANNON, D. L.; WIKLUND, J.; HAYNIE, J. M. The varying effects of family relationships in entrepreneurial teams. Entrepreneurship Theory and Practice, v. 37, n. 1, p. 107-132, 2013.

BRUNI, A.; GHERARDI, S.; POGGIO, B. Doing gender, doing entrepreneurship. An ethnographic account of intertwined practices. Gender, Work and Organization, v. 11, n. 4, p. 406-429, 2004.

BRUNI, A., GHERARADI, S.; POGGIO, B. Gender and Entrepreneurship. An Ethnographic Approach. London: Routledge, 2005.

BRUSH, C. G. Women entrepreneurs. A research overview. In: CASSON, M.; YEUNG, B.; BASU, A.; WADESON, N. (Eds.). The Oxford Handbook of Entrepreneurship. Oxford: Oxford University Press, 2008, p. 611-628.

CARTER, S. Improving the numbers and performance of women-owned businesses. Some implications for training and advisory services. Education and Training, v. 42, n. 4/5, p. 326-334, 2000.

CASSON, M.; GIUSTA, M. D. Entrepreneurship and social capital: analyzing the impact of social networks on entrepreneurial activity from a rational action perspective. International Small Business Journal, v. 25, n. 3, p. 220-244, 2007.

GUERREIRO, M. D.; CAETANO, A.; RODRIGUES, E.; BARROSO, M.; COUTO, A. I. Caminhos para o empreendedorismo: uma tipologia de acesso à atividade empreendedora. Revista de Empreendedorismo e Gestão de Pequenas Empresas, v.2,n.3, 2013. 
CLERCQ, D. D.; VORONOV, M. Toward a practice perspective of entrepreneurship. entrepreneurial legitimacy as habitus. International Small Business Journal, v. 27, n. 4, p. 395-419, 2009.

COPE, J. Researching entrepreneurship through phenomenological inquiry. Philosophical and methodological issues. International Small Business Journal, v. 23, n. 2, p. 163-189, 2005.

COPE, J.; JACK, S.; ROSE, M. B. Social capital and entrepreneurship. An introduction. International Small Business Journal, v. 25, n. 3, p. 213-219, 2007.

COSTA, A.F.; MACHADO, F. L.; ALMEIDA, J.F. Social classes and educational assets. A transnational analysis. In: COSTA, A. F.; MACHADO, F. L.; ÁVILA, P. Knowledge and Society, Portugal in the European Context, vol. II. Lisboa: Celta, 2009, p.5-20.

CRAIG, L.; POWELL, A.; CORTIS, N. Self-employment, work-family time and the gender division of labor. Work, Employment and Society, v. 26, n.5, p. 716-734, 2012.

CRAMER, L.; CAPELlE, M. C. A.; ANDRADE, A. L. S.; BRITO, M. J. Representações femininas da ação empreendedora: uma análise da trajetória das mulheres no mundo dos negócios. Revista de Empreendedorismo e Gestão de Pequenas Empresas, v. 1, n. 1, p. 53-71, 2012.

CROMPTON, R. Employment and the Family. The Reconfiguration of Work and Family Life in Contemporary Societies. Cambridge: Cambridge University Press, 2006.

CROMPTON, R. Restructuring Gender Relations and Employment. The Decline of the Male Breadwinner. Oxford: Oxford University Press, 1999.

CRUZ, A. D.; HOWORTH, C.; Hamilton, E. Intrafamily entrepreneurship. The formation and membership of family entrepreneurial teams. Entrepreneurship Theory and Practice, v. 37, n. 1, p. 17-46, 2013.

GUERREIRO, M. D.; CAETANO, A.; RODRIGUES, E.; BARROSO, M.; COUTO, A. I. Caminhos para o empreendedorismo: uma tipologia de acesso à atividade empreendedora. Revista de Empreendedorismo e Gestão de Pequenas Empresas, v.2,n.3, 2013. 
EDDLESTON, K. A.; POWELL, G. N. Nurturing entrepreneurs' work-family balance. A gendered perspective. Entrepreneurship Theory and Practice, v. 36, n. 3, p. 513-541, 2012.

ELAM, A. B. Gender and Entrepreneurship. A Multilevel Theory and Analysis. Cheltenham: Edward Elgar Publishing, 2008.

FENWICK, T. Transgressive desires. New enterprising selves in the new capitalism. Work, Employment and Society, v. 16, n. 4, p. 703-723, 2002a.

FENWICK, T. Lady, Inc. Women learning, negotiating subjectivity in entrepreneurial discourses. International Journal of Lifelong Education, v. 21, n. 2, p. 162-177, 2002b.

FILION, L. J. Empreendedorismo: empreendedores e proprietários-gerentes de pequenos negócios. Revista de Administração, v. 34, n. 2, p. 5-28, 1999.

FILION, L. J. Typologies d'entrepreneurs. Est-ce vraiment utile? In VERSTRAETE, T. (Ed.) Histoire d'entreprendre - Les réalités de l'entrepreneuriat. Caen: Éditions EMS, 2000, p.251-262.

FISCHER, E. M.; REUBER, A. R.; DYKE, L. S. A theoretical overview and extension of research on sex, gender and entrepreneurship. Journal of Business Venturing, v. 8, n. 2, p. 151-168, 1993.

GARCÍA, M. C. D.; WELTER, F. Gender identities and practices. Interpreting women entrepreneurs' narratives. International Small Business Journal. v.16, November 2011, DOI: 10.1177/0266242611422829.

GARCIA, R.; ARAÚJO, V.; MASCARINI, S.; SILVA, A. O.; ASCÚA, R. Empreendedorismo acadêmico no Brasil: uma avaliação á criação de empresas por alunos universitários. Revista de Empreendedorismo e Gestão de Pequenas Empresas, v. 1, n. 3, p. 36-63, 2012.

GIDDENS, A. The Constitution of Society. Outline of the Theory of Structuration. Cambridge: Polity Press, 1984.

GUERREIRO, M. D.; CAETANO, A.; RODRIGUES, E.; BARROSO, M.; COUTO, A. I. Caminhos para o empreendedorismo: uma tipologia de acesso à atividade empreendedora. Revista de Empreendedorismo e Gestão de Pequenas Empresas, v.2,n.3, 2013. 
GOIS, P. H.; MACHADO H. P. V. Uma abordagem sobre o papel das redes para pequenas empresas e sobre os efeitos no aprendizado de empreendedores. Revista de Empreendedorismo e Gestão de Pequenas Empresas, v. 1, n. 1, p. 32-52, 2012.

GORMAN, G,; HANLON, D.; KING, W. Some research perspectives on entrepreneurship education, enterprise education and education for small business management. A ten-year literature review. International Small Business Journal, v. 15, n. 3, p. 56-77, 1997.

GREVE, A.; SALAFF, J. W. Social networks and entrepreneurship. Entrepreneurship Theory and Practice, v. 28, n. 1, p. 1-22, 2003.

HOCHSCHILD, A. The Second Shift. Working Parents and the Revolution at Home. Berkeley: University of California Press, 1989.

HOWORTH, C.; ALI, Z.A. Family business succession in Portugal. An examination of case studies in the furniture industry. Family Business Review, v. 14, n. 3, p. 231244, 2001.

HOWORTH, C.; ROSE, M.; HAMILTON, E.; WESTHEAD, P. Family firm diversity and development. An introduction. International Small Business Journal, v. 28, n. 5, p. 437-451, 2010.

HUGHES, K. D. Pushed or pulled? Women's entry into self-employment and small business ownership. Gender, Work and Organization, v. 10, n. 4, p. 433-454, 2003.

JOHANSSON, A. W. Narrating the entrepreneur. International Small Business Journal, v. 22, n. 3, p. 273-293, 2004.

JONES, S. Gendered discourses of entrepreneurship in UK higher education. The fictive entrepreneur and the fictive student. International Small Business Journal, Epub ahead of print 17 September 2012, DOI: 10.1177/0266242612453933.

KANTER, R. M. Men and Women of the Corporation. New York: Basic Books, 1993 [1977].

GUERREIRO, M. D.; CAETANO, A.; RODRIGUES, E.; BARROSO, M.; COUTO, A. I. Caminhos para o empreendedorismo: uma tipologia de acesso à atividade empreendedora. Revista de Empreendedorismo e Gestão de Pequenas Empresas, v.2,n.3, 2013. 
KELLEY, D. J.; BRUSH, C. G.; GREENE, P. G., LITOVSKY, Y. GEM 2012 Women's Report. Babson Park: Babson College, 2013.

KIM, P. H.; ALDRICH, H.E. Social Capital and Entrepreneurship. Delft: Now Publishers, 2005.

KOBEISSI, N. Gender factors and female entrepreneurship. International evidence and policy implications. Journal of International Entrepreneurship, v. 8, n. 1, p. 135, 2010.

KURATKO, D. F. The emergence of entrepreneurship education. Development, trends, and challenges. Entrepreneurship Theory and Practice, v. 29, n. 5, p. 577598, 2005.

LAHIRE, B. Retratos Sociológicos. Disposições e Variações Individuais. São Paulo: Artmed, 2004.

LARTY, J.; HAMILTON, E. Structural approaches to narrative analysis in entrepreneurship research. Exemplars from two researchers. International Small Business Journal, v. 29, n. 3, p. 220-237, 2011.

LEWIS, P. The quest for invisibility. Female entrepreneurs and the masculine norm of entrepreneurship. Gender, Work and Organization, v. 13, n. 5, p. 453-469, 2006.

LEWIS, S.; DOORNIE-HUSKIES, A.; REDAY, D.; BARROSO, M. The healthy organization. In: BACK-WIKLUND, M.; VAN DER LIPPE, T.; DEN DULK, L.; DOORNE-HUISKES, A. Quality of Life and Work in Europe. Theory, Practice and Policy. London: Palgrave, 2011, p.165-185.

MAN, T. W. Y. Exploring the behavioral patterns of entrepreneurial learning. A competency approach. Education and Training, v. 48, n. 5, p. 309-321, 2006.

MARCHESNAY, M. Some insights into French entrepreneurship research - from the hypofirm model to the PIE and GAP typology. International Journal of Entrepreneurship and Small Business. v. 13, n. 2, p.150-161, 2011.

GUERREIRO, M. D.; CAETANO, A.; RODRIGUES, E.; BARROSO, M.; COUTO, A. I. Caminhos para o empreendedorismo: uma tipologia de acesso à atividade empreendedora. Revista de Empreendedorismo e Gestão de Pequenas Empresas, v.2,n.3, 2013. 
MARLOW, S.; HENRY, C.; CARTER, S. Exploring the impact of gender upon women's business ownership. Introduction. International Small Business Journal, v. 27, n. 2, p. 139-148, 2009.

MATLAY, $H$. The impact of entrepreneurship education on entrepreneurial outcomes. Journal of Small Business and Enterprise Development, v. 15, n. 2, p. 382-396, 2008.

NABI, G.; HOLDEN, R. Graduate entrepreneurship. Intentions, education and training. Education and Training, v. 50, n. 7, p. 545-551, 2008.

NABI, G.; HOLDEN, R.; WALMSLEY, A. Graduate career-making and business startup. A literature review. Education and Training, v. 48, n. 5, p. 373-385, 2006.

OECD. Entrepreneurship at a Glance 2012. OECD Publishing, 2012.

PATTERSON, N.; MAVIN, S. Women entrepreneurs. Jumping the corporate ship and gaining new wings. International Small Business Journal, v. 27, n. 2, p. 173-192, 2009.

PITTAWAY, L.; COPE, J. Entrepreneurship education. A systematic review of the evidence. International Small Business Journal, v. 25, n. 5, p. 479-510, 2007.

PITTAWAY, L.; RODRIGUEZ-FALCON, E.; AIYEGBAYO, O.; KING, A. The role of entrepreneurship clubs and societies in entrepreneurial learning. International Small Business Journal, v. 29, n. 1, p. 37-57, 2010.

POWELL, G. N. Women and Men in Management. London: Sage, 2010.

PRÄG, P.; GUERREIRO, M. D.; NÄTTI, J.; BROOKES, M.; DEN DULK, L. Quality of work and quality of life of service sector workers. Cross-national variations in eight European countries. In: BACK-WIKLUND, M.; VAN DER LIPPE, T.; DEN DULK, L.; DOORNE-HUISKES, A. (Eds.). Quality of Life and Work in Europe. Theory, Practice and Policy. London: Palgrave, 2011, p.77-94.

RASMUSSEN, E. Understanding academic entrepreneurship. Exploring the emergence of university spin-off ventures using process theories. International Small Business Journal, v. 29, n. 5, p. 448-471, 2011.

GUERREIRO, M. D.; CAETANO, A.; RODRIGUES, E.; BARROSO, M.; COUTO, A. I. Caminhos para o empreendedorismo: uma tipologia de acesso à atividade empreendedora. Revista de Empreendedorismo e Gestão de Pequenas Empresas, v.2,n.3, 2013. 
RIBEIRO, T. M.; TEIXEIRA, R. M. A criação de negócios por empreendedores jovens: estudo de casos múltiplos no estado de Sergipe. Revista de Empreendedorismo e Gestão de Pequenas Empresas, v. 1, n. 1, p. 72-100, 2012.

ROBICHAUD, Y.; ZINGER, J. T.; LEBRASSEUR, R. Gender differences within early stage and established small enterprises. An exploratory study. International Entrepreneurship and Management Journal, v. 3, n. 3, p. 323-343, 2007.

ROBSON, P. J. A.; WIJBENGA, F.; PARKER, S. C. Entrepreneurship and policy. Challenges and directions for future research. International Small Business Journal, v. 27, n. 5, p. 531-535, 2009.

TAATILA, V. P. Learning entrepreneurship in higher education. Education and Training, v. 52, n. 1, p. 48-61, 2010.

THORNTON, P. H. The sociology of entrepreneurship. Annual Review of Sociology, v. 25, p. 19-46, 1999.

THORNTON, P. H.; RIBEIRO-SORIANO, D.; URBANO, D. Socio-cultural factors and entrepreneurial activity. An overview. International Small Business Journal, v. 29, n. 2, p. 105-118, 2011.

URBANO, D.; TOLEDANO, N.; RIBEIRO-SORIANO, D. Socio-cultural factors and transnational entrepreneurship. A multiple case study in Spain. International Small Business Journal, v. 29, n. 2, p. 119-134, 2011.

VERHEUL, I.; RISSEEUW, P.; BARTELSE, G. Gender differences in strategy and human resource management. The case of Dutch real estate brokerage. International Small Business Journal, v. 20, n. 4, p. 443-476, 2002.

VERHEUL, I.; THURIK, R. Start-up capital: 'does gender matter?'. Small Business Economics, v. 16, n. 4, p. 329-345, 2001.

WELTER, F. Contextualizing entrepreneurship. Conceptual challenges and ways forward. Entrepreneurship Theory and Practice, v. 35, n. 1, p. 165-184, 2011.

GUERREIRO, M. D.; CAETANO, A.; RODRIGUES, E.; BARROSO, M.; COUTO, A. I. Caminhos para o empreendedorismo: uma tipologia de acesso à atividade empreendedora. Revista de Empreendedorismo e Gestão de Pequenas Empresas, v.2,n.3, 2013. 
XAVIER, S.R.; KELLEY, D.; KEW, J.; HERRINGTON, M.; VORDERWÜLBECKE, A. GEM 2012 Global Report. Babson Park: Babson College, 2013.

ZELLWEGER, T. M.; NASON, R. S.; NORDQVIST, M. From longevity of firms to transgenerational entrepreneurship of families. Introducing family entrepreneurial orientation. Family Business Review, v. 25, n. 2, p. 136-155, 2012.

\footnotetext{
' Na última década têm ganho particular visibilidade abordagens sobre o empreendedorismo de cariz etnográfico (BRUNI ET AL., 2004, 2005) e mais centradas nas experiências individuais e nas narrativas dos empreendedores (COPE, 2005; JOHANSSON, 2004; LARTY E HAMILTON, 2011).

ii Os kits de produção doméstica de cogumelos consistem em embalagens com um preparado no interior pronto para o crescimento de cogumelos comuns para consumo culinário.
}

Artigo recebido em:16/10/2013 Aprovado em:05/12/2013.

GUERREIRO, M. D.; CAETANO, A.; RODRIGUES, E.; BARROSO, M.; COUTO, A. I. Caminhos para o empreendedorismo: uma tipologia de acesso à atividade empreendedora. Revista de Empreendedorismo e Gestão de Pequenas Empresas, v.2,n.3, 2013. 